\title{
Portugal: 2006 Article IV Consultation-Staff Report; Staff Statement; Public Information Notice on the Executive Board Discussion; and Statement by the Executive Director for Portugal
}

Under Article IV of the IMF's Articles of Agreement, the IMF holds bilateral discussions with members, usually every year. In the context of the 2006 Article IV consultation with Portugal, the following documents have been released and are included in this package:

- $\quad$ the staff report for the 2006 Article IV consultation, prepared by a staff team of the IMF, following discussions that ended on July 17, 2006, with the officials of Portugal on economic developments and policies. Based on information available at the time of these discussions, the staff report was completed on September 20, 2006. The views expressed in the staff report are those of the staff team and do not necessarily reflect the views of the Executive Board of the IMF.

- $\quad$ a staff statement of October 18, 2006 updating information on recent developments.

- $\quad$ a Public Information Notice (PIN) summarizing the views of the Executive Board as expressed during its October 18, 2006 discussion of the staff report that concluded the Article IV consultation.

- $\quad$ a statement by the Executive Director for Portugal.

The documents listed below have been or will be separately released.

Financial System Stability Assessment

Selected Issues Paper

The policy of publication of staff reports and other documents allows for the deletion of market-sensitive information.

To assist the IMF in evaluating the publication policy, reader comments are invited and may be sent by e-mail to publicationpolicy@imf.org.

Copies of this report are available to the public from

International Monetary Fund $\bullet$ Publication Services

$70019^{\text {th }}$ Street, N.W. • Washington, D.C. 20431

Telephone: (202) 623-7430 • Telefax: (202) 623-7201

E-mail: publications@imf.org Internet: http://www.imf.org

Price: $\$ 18.00$ a copy

International Monetary Fund

Washington, D.C. 

INTERNATIONAL MONETARY FUND

PORTUGAL

\section{Staff Report for the 2006 Article IV Consultation}

Prepared by Staff Representatives for the 2006 Consultation with Portugal

Approved by Poul M. Thomsen and G. Russell Kincaid

September 20, 2006

- $\quad$ Messrs. Gerson (head), Drummond, and Xiao (all EUR), and Giustiniani (MFD) visited Lisbon on July 6-17. They met with the Ministers of Finance and Economy; the Governor of the Bank of Portugal; members of Parliament; and representatives of regulatory agencies, local governments, financial entities, and labor and business organizations. Mr. Saramago (OED) attended most meetings.

- A Socialist Party government took office in March 2005. Parliamentary elections are due by 2009 .

- $\quad$ Portugal has accepted the obligations of Article VIII, Sections 2, 3, and 4, and maintains an exchange system free of restrictions, except for those maintained solely for the preservation of national or international security, and which have been notified to the Fund pursuant to Executive Board Decision No. 144(52/51); see Appendix 1.

- In concluding the last Article IV consultation, Directors stressed the need for further progress in addressing fiscal vulnerabilities and for action on structural measures to increase productivity and improve competitiveness. (http://www.imf.org/external/np/sec/pn/2005/pn05147.htm)

- Data provision to the Fund is adequate for surveillance purposes. 


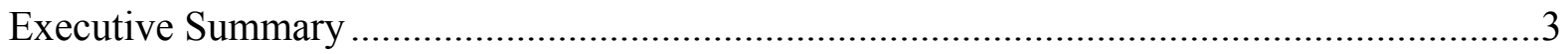

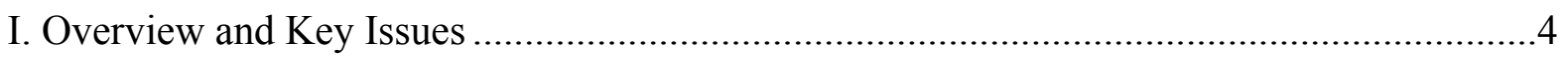

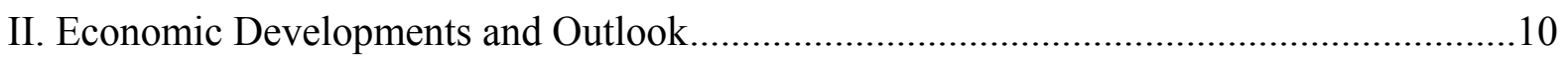

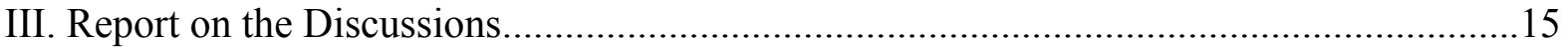

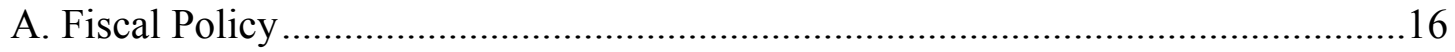

B. Revitalizing Growth and Restoring Competitiveness ................................... 18

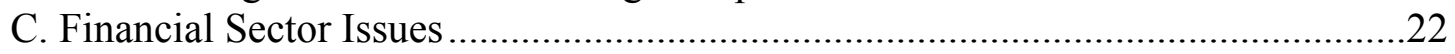

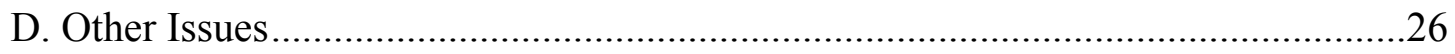

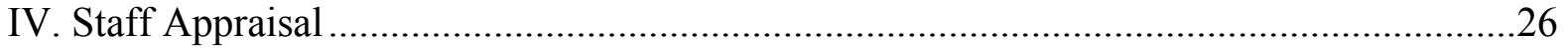

Boxes

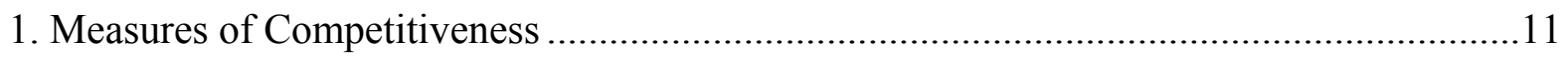

2. Fund Policy Recommendations and Implementation ............................................. 12

3. Understanding Investment Behavior in Portugal........................................................ 14

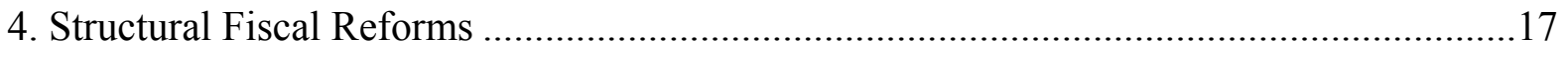

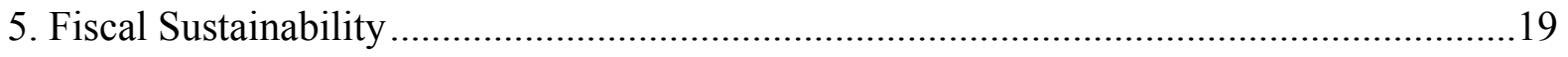

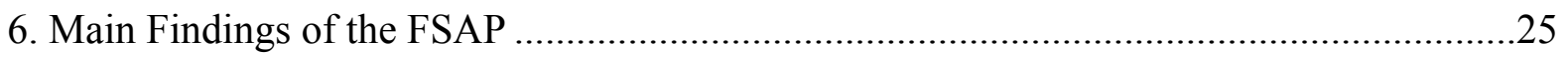

Tables

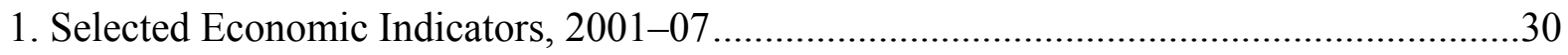

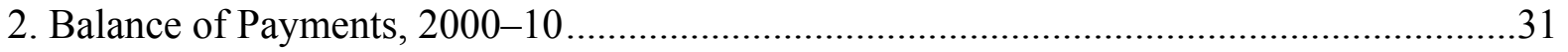

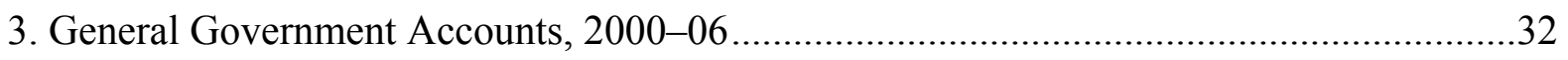

4. External Debt Sustainability Framework, 2001-11 ......................................................33

5. Public Sector Debt Sustainability Framework, 2001-11 ...............................................34

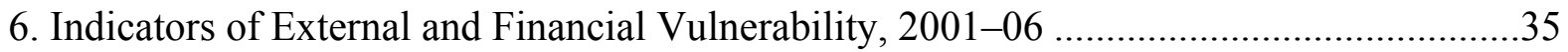

7. Selected Financial Indicators of the Banking System, 2000-05 .....................................36

Figures

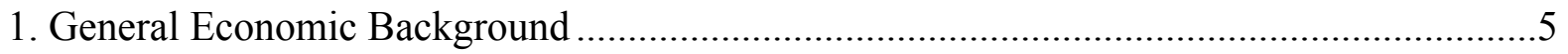

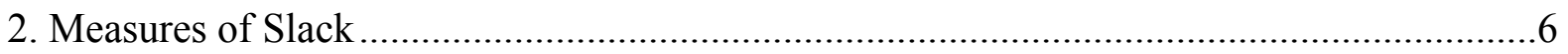

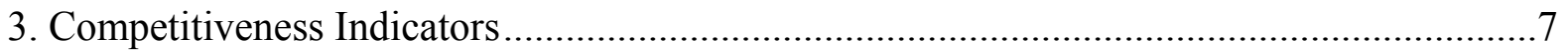

4. External Current Account and Its Financing, 2000-05 ..............................................8

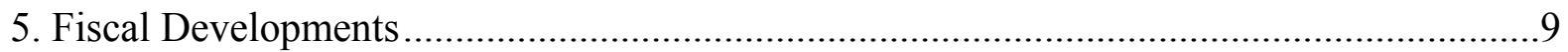

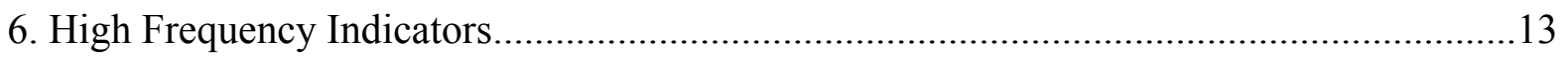

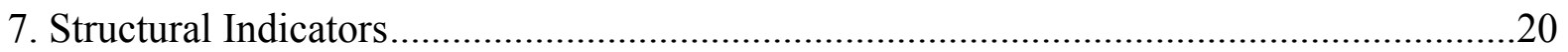

8. Employment Protection Legislation (EPL) Strictness Indicators, 2003 ............................23

9. Credit and Asset Market Developments, 2000-05 ........................................................24

Appendixes

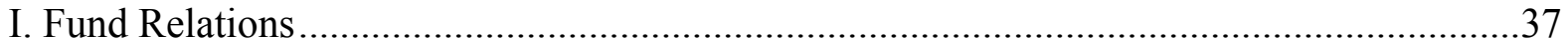

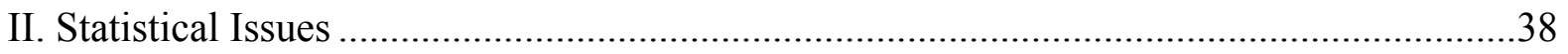




\section{EXECUTIVE SUMMARY}

\section{Recent developments and prospects}

A mild recovery is underway but the economic environment remains difficult. Several years of rapidly rising unit labor costs have substantially undermined competitiveness. Investment has collapsed, the unemployment rate has doubled, the 2005 fiscal deficit reached 6 percent of GDP, and the current account deficit has swollen to more than 9 percent of GDP. A lengthy period of adjustment will be required not only to restore external competitiveness but also to ensure the sustainability of public finances.

\section{Key policy requirements}

The authorities' program emphasizes fiscal consolidation based on high-quality and durable expenditure measures and structural reforms to increase productivity and restore competitiveness. Timely and decisive implementation of these initiatives will be necessary to maintain the credibility of the government's program.

Securing fiscal consolidation: The 2006 budget plans a reduction in the deficit to 4.6 percent of GDP, implying just over $1 \frac{1}{2}$ percentage points of structural adjustment. The authorities were confident the deficit target would be achieved but committed to undertake additional measures if needed. The authorities expect major structural fiscal reforms to be in effect next year but acknowledged that their yield was difficult to forecast, and the staff urged that their impact be assessed cautiously in the 2007 budget. Additional adjustment will be required even after 2008, when the deficit is programmed to fall below 3 percent of GDP, in light of the projected fiscal effects of population aging.

Restoring competitiveness: Some progress has already been achieved in improving the business environment and stimulating greater domestic competition. The authorities' Technological Plan aims to support private investment in R\&D and IT, but further enhancements to the business environment will remain a priority. The authorities continue to assign a lower priority to labor market reform, arguing that de facto employment protection is weaker than standardized indicators suggest. The staff views reforms to employment protection legislation and collective bargaining arrangements as an essential component of any strategy to contain unit labor costs.

Safeguarding the financial sector: The FSAP found that the financial sector has weathered the weak macroeconomic environment of recent years well, and no major changes are called for in prudential arrangements. Key risks arise from high household and corporate debt levels, concentrated bank lending, and banks' exposure to equity price fluctuations through their employee pension funds. Staff encouraged the authorities to keep these risks under close monitoring and to implement FSAP recommendations. 


\section{OVERVIEW AND KEY ISSUES}

\section{Reestablishing income convergence and resolving large fiscal and external} imbalances remain Portugal's key challenges. Growth has averaged just over $1 / 2$ percent since 2000 (Figures 1 and 2), in part due to rapidly rising unit labor costs that have substantially undermined competitiveness (Figure 3). Investment has collapsed, the unemployment rate has doubled, and the current account deficit has swollen to more than 9 percent of GDP (Figure 4). Owing partly to slow growth, but more fundamentally to rising primary spending and the abandonment of one-off measures, the SGP-monitored fiscal deficit reached 6 percent of GDP last year, leading to the launching of the second Excessive Deficit Procedure by the EU in just three years (Figure 5). Portugal confronts a difficult environment, with sizable fiscal and balance of payments deficits; a weak competitive position, especially within an enlarged EU; and high private indebtedness.

\section{A sustained period of adjustment will be needed to restore external} competitiveness and the sustainability of the public finances. A sharp fall in total factor

productivity lies at the root of Portugal's poor growth performance: over the period 2001-04, TFP grew at an average annual rate of 0.9 percent in the euro area but fell at a rate of 0.7 percent in Portugal, accounting for all of the difference in growth of output per hour worked between the two entities. Over 1996-2004, annual TFP growth averaged 1.0 percent in the euro area but just
Portugal and the Euro Area: Ouput Per Labor Hour (Average annual growth rate, in percent)

\begin{tabular}{|c|c|c|c|c|}
\hline & & \multirow[b]{2}{*}{$\begin{array}{l}\text { Output per } \\
\text { labor hour } \\
\end{array}$} & \multicolumn{2}{|c|}{ Of which } \\
\hline & & & $\begin{array}{c}\text { Capital } \\
\text { deepening } \\
\end{array}$ & $\begin{array}{c}\text { TFP } \\
\text { growth }\end{array}$ \\
\hline \multirow[t]{2}{*}{ Euro area } & 2001-2004 & 1.6 & 0.8 & 0.9 \\
\hline & 1996-2004 & 1.6 & 0.5 & 1.0 \\
\hline \multirow[t]{2}{*}{ Portugal } & 2001-2004 & 0.0 & 0.8 & -0.7 \\
\hline & 1996-2004 & 1.8 & 1.5 & 0.2 \\
\hline
\end{tabular}
0.2 percent in Portugal. Poor TFP growth can be traced to very low levels of human capital, but also to shortcomings in the business environment - including excessive regulation and a slow legal framework - and to insufficient competition in domestic markets, especially in key network sectors where some former-monopolies maintain a dominant share. While the growth impact of measures to address these problems is difficult to quantify, it is potentially very significant: a recent study by McKinsey has estimated that about two-thirds of the gap between Portuguese per capita GDP and that of the top five EU countries could be eliminated over time through improvements to the policy environment. ${ }^{1}$ Meanwhile, growth of nominal wages has dramatically exceeded that of productivity, notwithstanding a rise in unemployment, suggesting the presence of significant labor market rigidities. Staff analysis

\footnotetext{
${ }^{1}$ McKinsey Global Institute (2003) Portugal 2010: Increasing Productivity in Portugal.
} 
Figure 1. Portugal: General Economic Background

Growth has continued to slide...
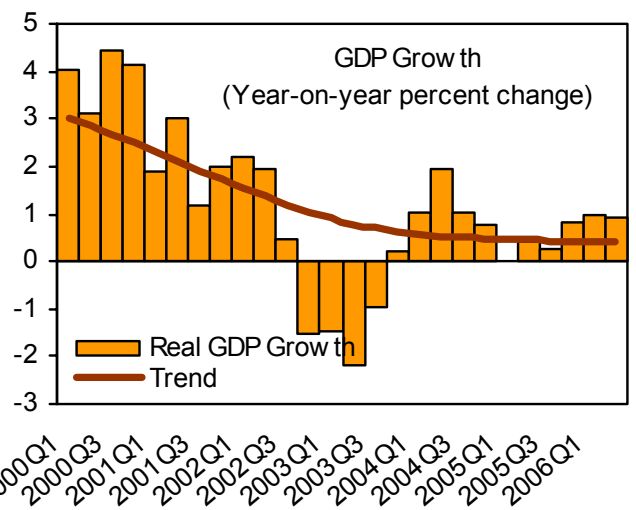

thanks to weak investment,

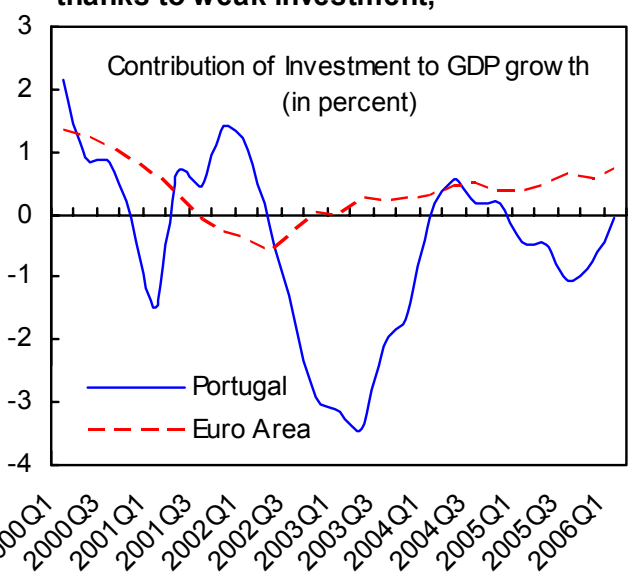

some cooling off of public consumption...

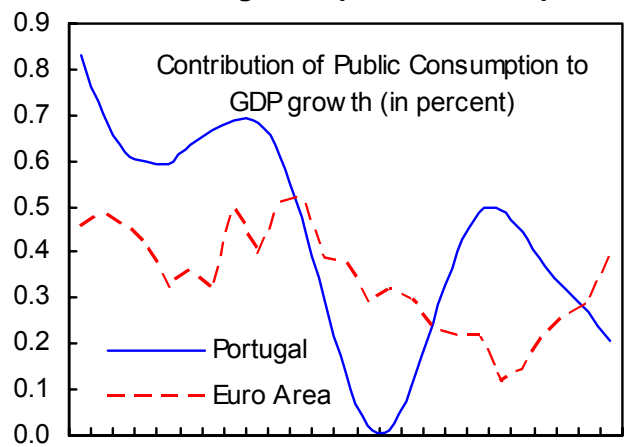

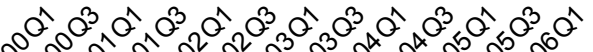

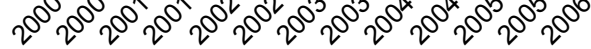

and the convergence process has

moved into reverse..

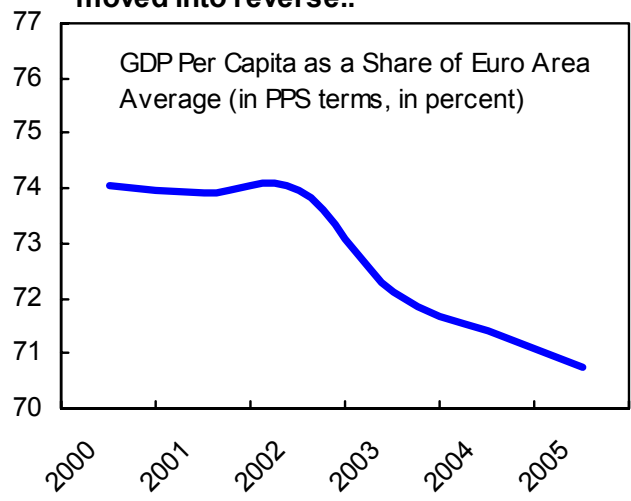

\section{moderating private consumption,}

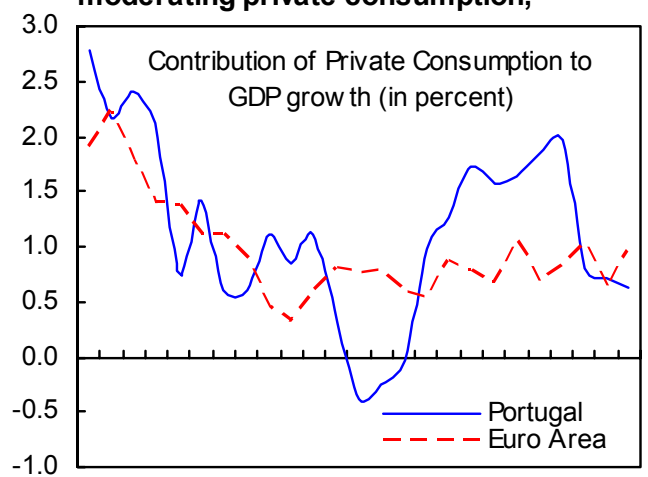

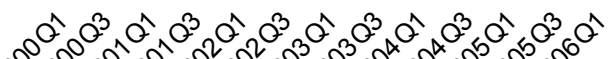

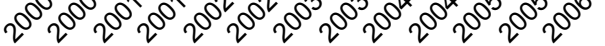

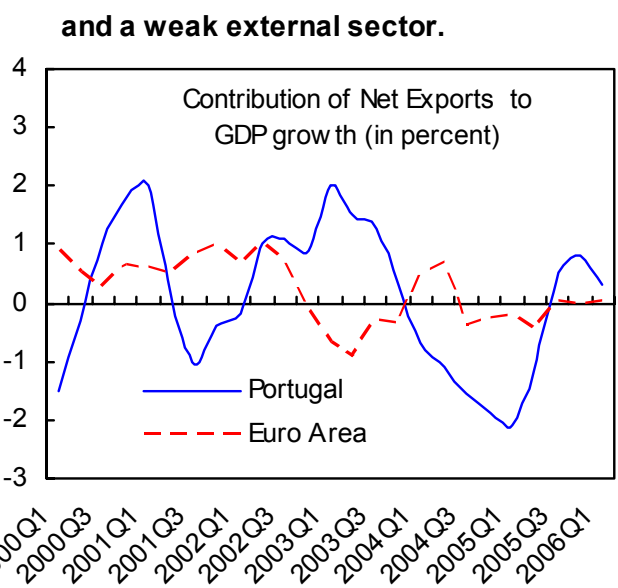

Source: Bank of Portugal; National Institute of Statistics (INE); and Fund staff calculations. 
Figure 2. Portugal: Measures of Slack

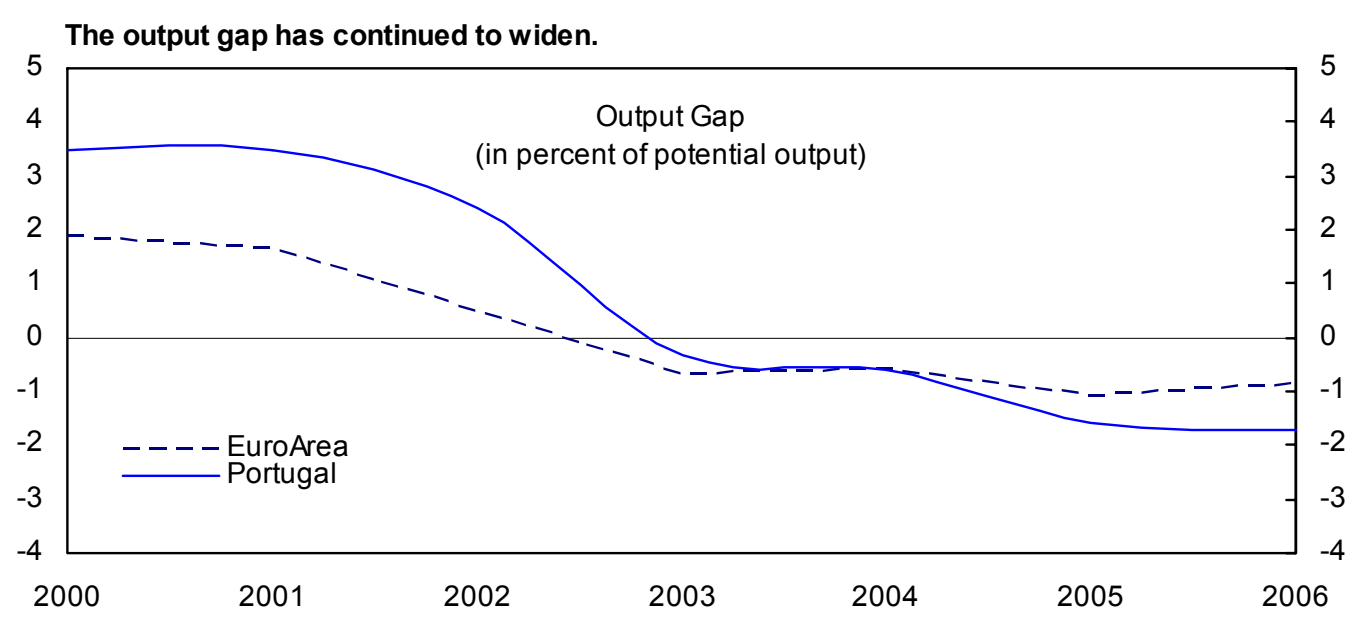

The unemployment rate has doubled since 2000 .

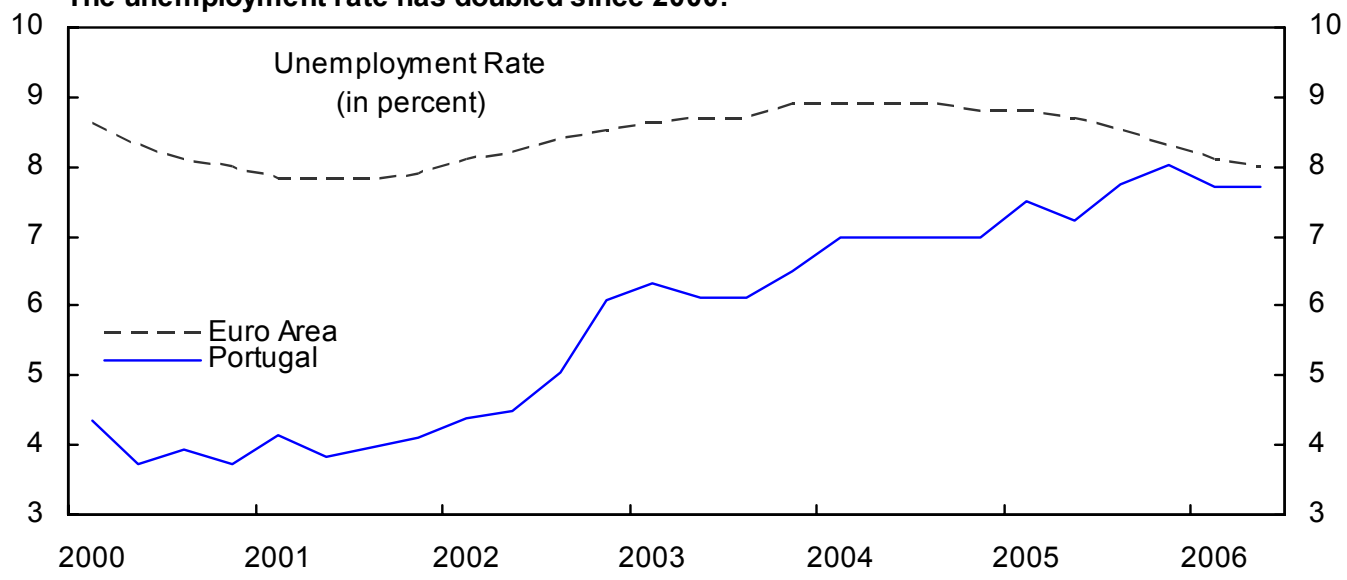

And employment has largely stagnated for three years.

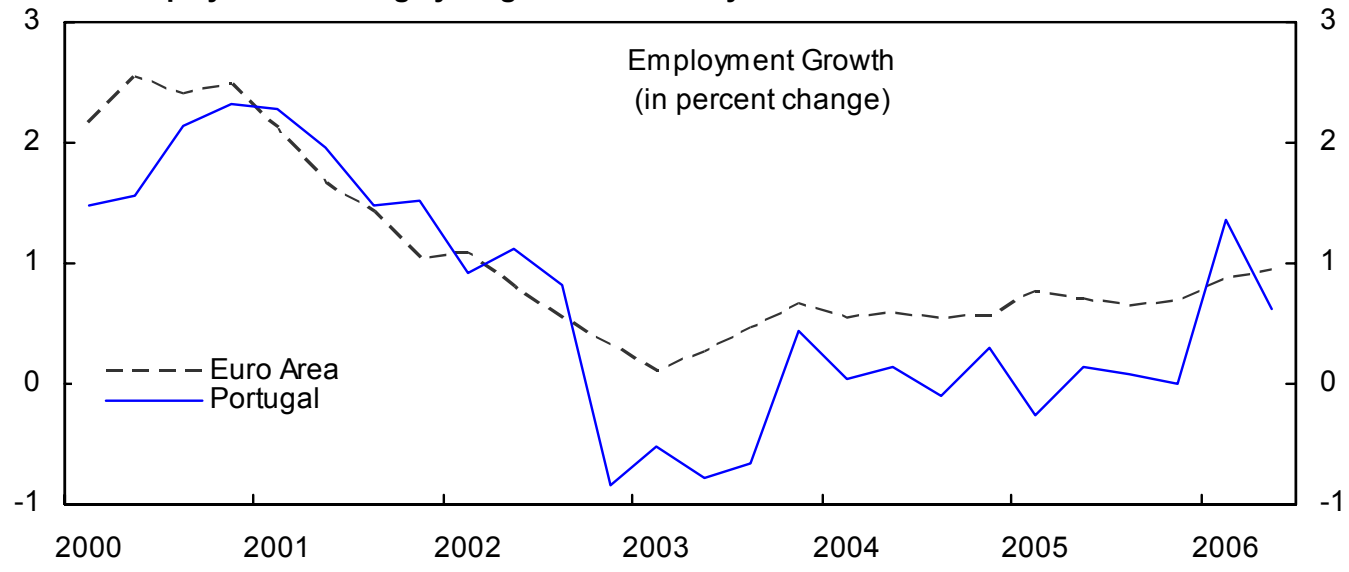

Source: Bank of Portugal; National Statistics Office (INE); and Eurostat. 
Figure 3. Portugal: Competitiveness Indicators

The REER has appreciated sharply.

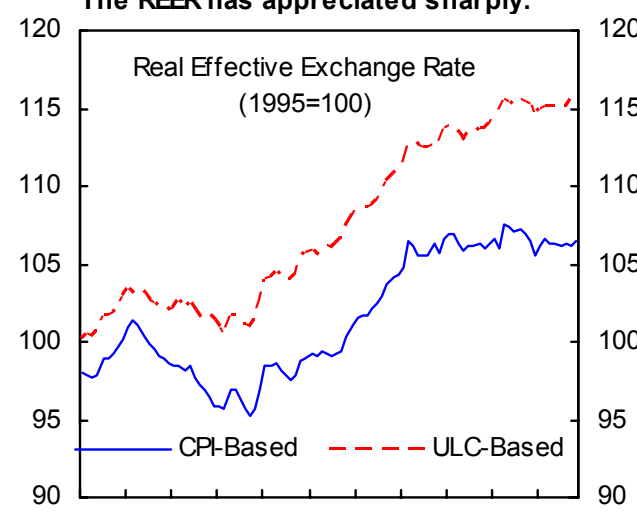

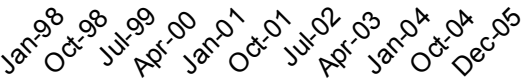

and lagging productivity grow th...
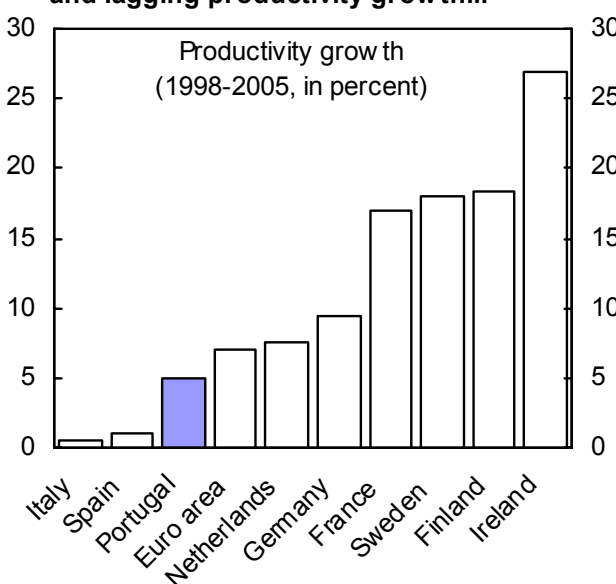

Employment in sectors more open to competition has declined.

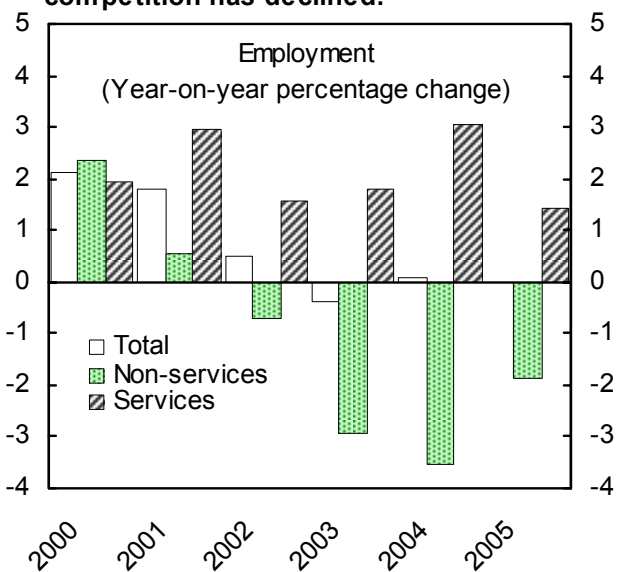

Rapid wage growth...
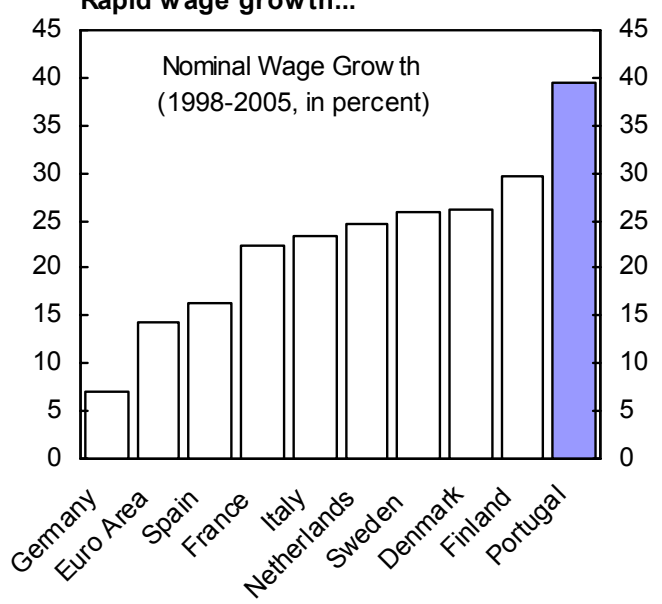

have priced out Portuguese workers.

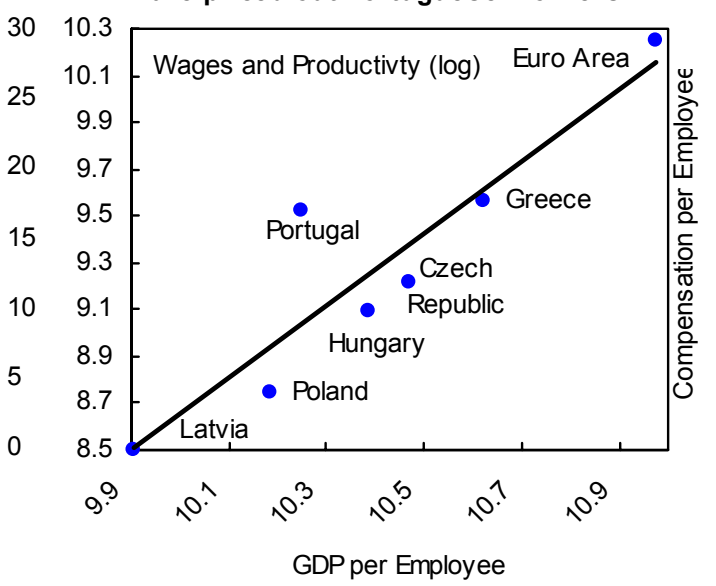

And export performance has been weak

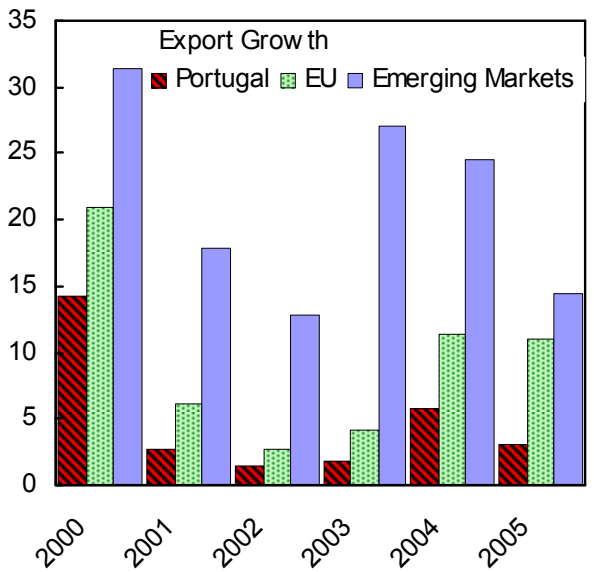

Source: AMECO database; National Institute of Statistics (INE); Eurostat; and Fund staff calculations. 
Figure 4. Portugal: External Current Account and its Financing, 2000-05

(In percent of GDP, unless otherwise indicated)
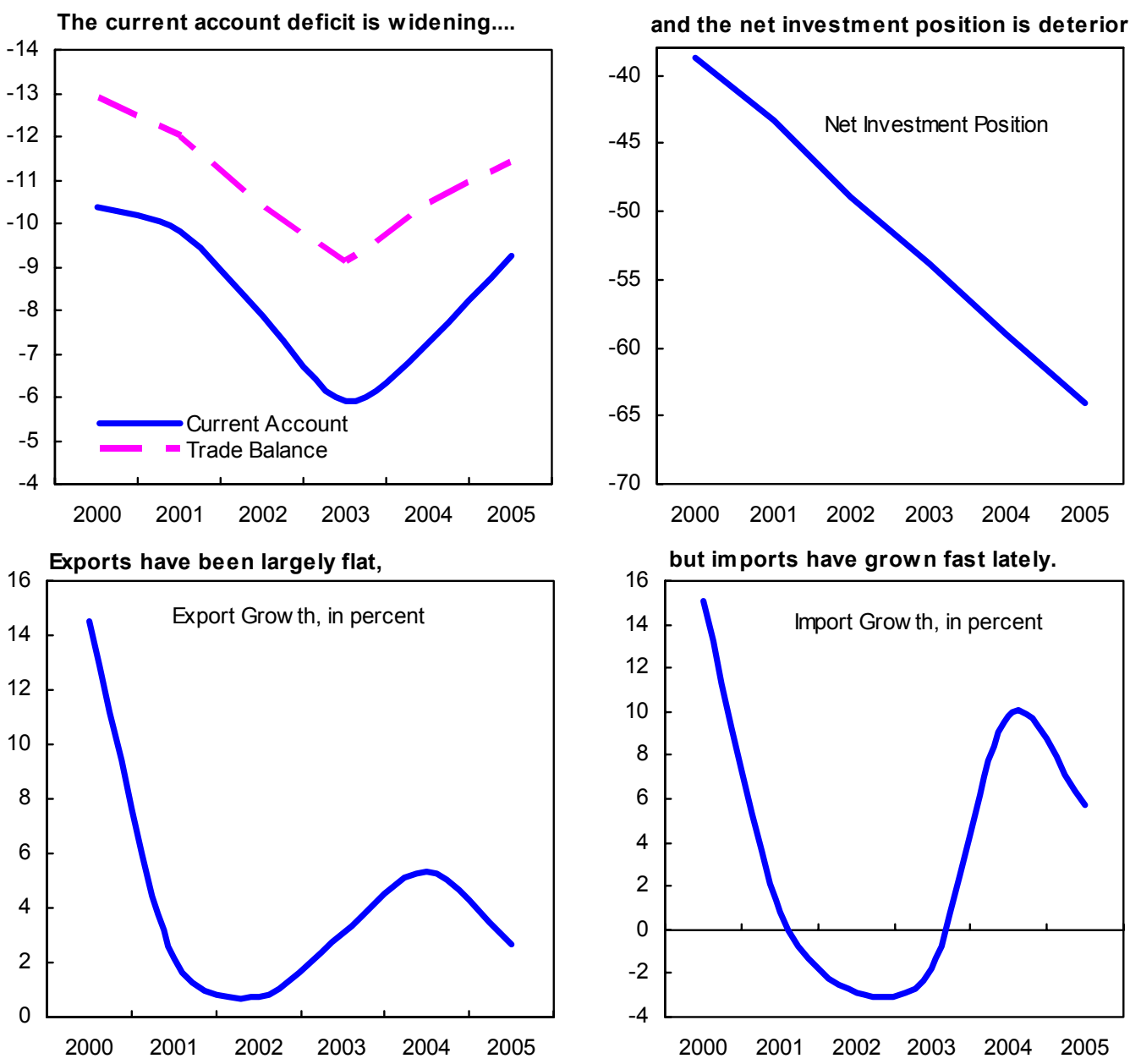

FDI has dwindled...

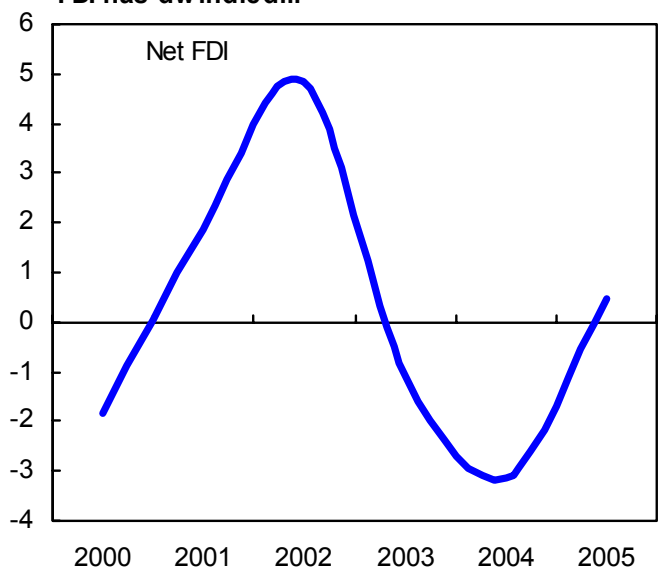

while banks' net foreign liabilities diminished

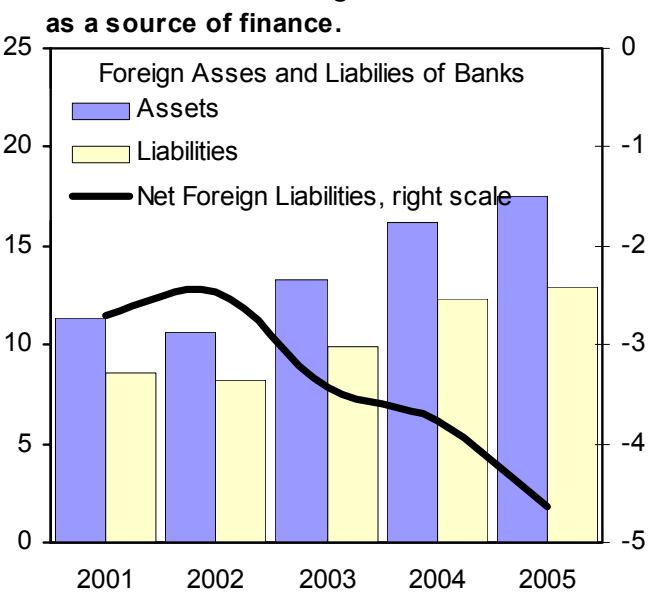

Source: Bank of Portugal 
Figure 5. Portugal: Fiscal Developments

(In percent of GDP, unless otherwise indicated)
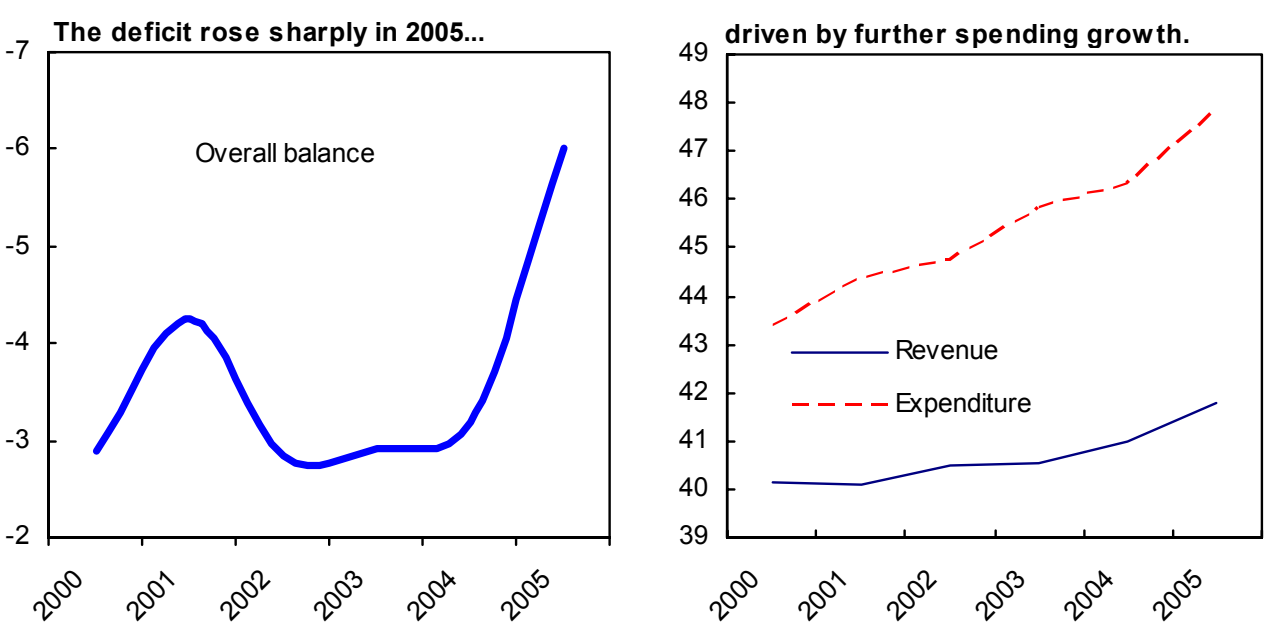

The deficit excluding one-off measures grew less.
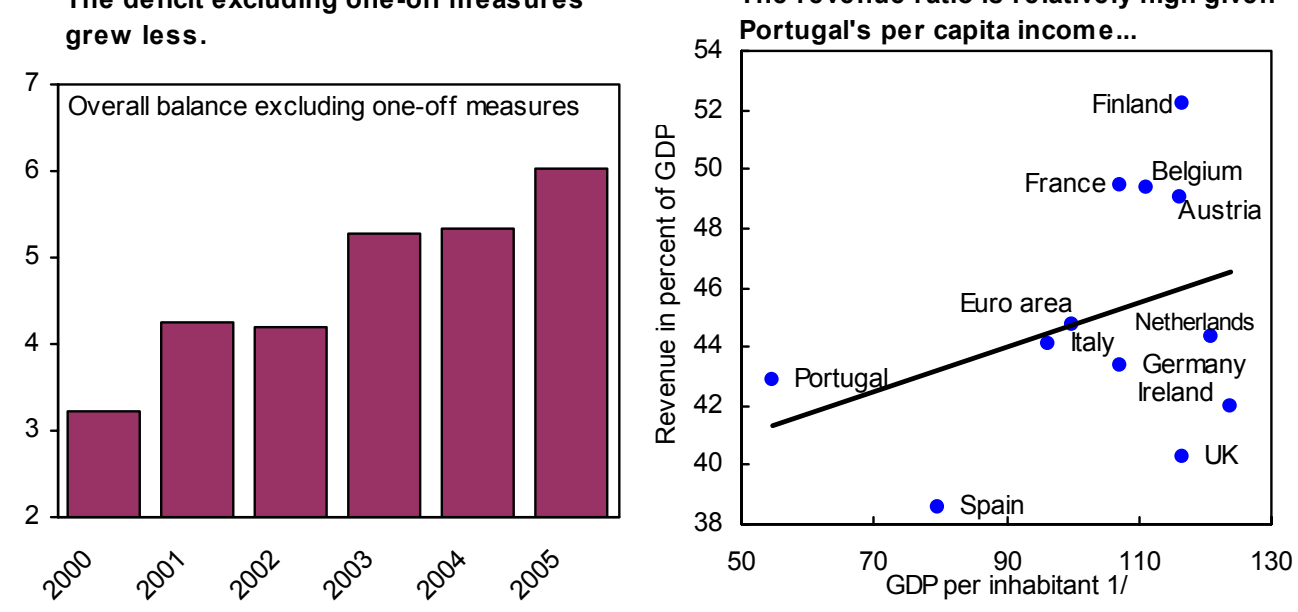

... as is spending.
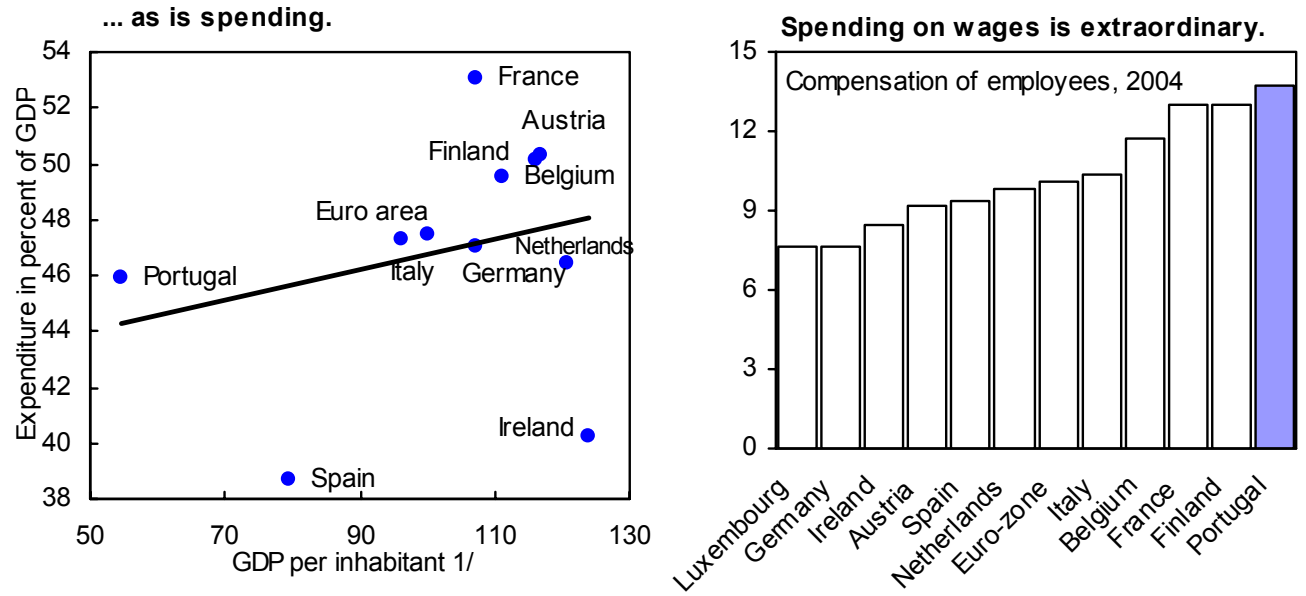

Source: Bank of Portugal, Fund's staff calculations, Eurostat.

1/ For Ireland, GNP per inhabitant. 
points to a substantial loss of competitiveness that will take years to fully reverse even with strong productivity growth and considerable wage moderation (Box 1 ). ${ }^{2}$ Restoring the sustainability of the fiscal accounts will likewise demand continued consolidation into the next decade.

3. The strategy laid out last year by the government to confront these challenges set appropriate objectives. The main elements of the strategy were threefold:

- $\quad$ Fiscal consolidation to bring the deficit under 3 percent of GDP by 2008 without oneoff measures;

- $\quad$ Structural fiscal reforms to contain aging-related spending and raise the efficiency and quality of public spending, to promote the sustainability of the public finances; and

- $\quad$ Reforms to enhance competition in product markets and improve the business environment, with a view toward spurring productivity growth.

4. Progress with some bedrock structural reforms has been slow, however, and redoubled efforts are needed to safeguard the credibility of the government's program. Reforms of the civil service pension scheme and health sector have been introduced, and recent initiatives have reduced bureaucratic red tape (Box 2.) However, some critical planned structural fiscal reforms - to the civil service, to the structure of the public sector, and to the social security system for private sector workers - had as of mid-2006 yet to be enacted. Recently, momentum on these reforms has been restored, but even after their approval rigorous implementation will be required. Some progress has been achieved in improving the business environment, but more needs to be done-especially in labor markets - to facilitate investment and innovation, promote wage moderation, and reverse competitiveness losses.

\section{ECONOMIC DEVELOPMENTS AND OUTLOOK}

5. A gradual recovery is underway after a largely flat 2005, but the authorities and the mission expected growth to remain relatively slow in the short-term. Staff projects growth of 1.2 percent in 2006 and 11/2 percent in 2007, in line with official forecasts and recent high frequency indicators (Figure 6).

- $\quad$ Strong foreign demand is expected to lead to a better external contribution to growth than in previous years.

\footnotetext{
${ }^{2}$ See the accompanying Selected Issues Paper.
} 


\section{Box 1. Measures of Competitiveness}

\section{A range of indicators point to a competitiveness gap versus other euro-area} members of 10-20 percent. Portugal's ULC-based real effective exchange rate has appreciated by about 10 percent since the mid 1990s (the benchmark period for Portugal). Over the same period, unit labor costs in manufacturing rose some 20 percentage points faster than for euro-area competitors, and profit margins for Portuguese exporters fell by 15 percent relative to those of exporters from other euroarea countries. Smidkova and Bulir's (2004) estimates of fundamental exchange rates indicate that by end-2003 the euro was 10-20 percent too strong in real terms for Portugal. Staff estimates suggest that a real depreciation of 12-20 percent would be needed to generate a trade balance consistent with stabilizing net external liabilities at their 2005 level.

The loss in competitiveness is reflected in export data.

Constant market share analysis suggests the bulk of export market loss in the 1990s was associated with deteriorating competitiveness (see table). It also points to a moderation in competitiveness losses since 1998, at the expense of a substantial compression of margins.
CMS Analysis of Exports Changes

(Changes in percent; unless otherwise indicated)

\begin{tabular}{lrr}
\hline & 1992-2004 & 1998-2004 1/ \\
\hline Exports (annual growth rate, in percent) & 5.6 & 6.7 \\
Contribution (in percent) & & \\
World Trade Effect & 12.2 & 8.0 \\
Commodity Composition Effect & -2.2 & -1.4 \\
Market Distribution Effect & 3.2 & 2.2 \\
Competitiveness & -7.6 & -2.2 \\
\hline
\end{tabular}

Source: IMF Staff estimates.

1/ Based on the commodity composition of exports as of 1998 .

Closing the competitiveness gap will likely require a long adjustment period, even with a dramatic jump in TFP growth and strong wage moderation. Assuming future ULC growth of 1 percent annually for the euro area (as in the April 2006 WEO projections), even if Portuguese ULCs were to fall at a rate of 2 percent annually it would still take three-seven years to close the competitiveness gap with the euro area. Moreover, if capital deepening were to contribute 1 percent annually to labor productivity growth over that period (slightly above the rate experienced in 2001-04), even an increase in annual TFP growth to 1 percent (the euro-area average for those years) would leave no room for nominal wage growth in Portugal under this scenario. While these calculations are simply illustrative, and are - as the authorities pointed out - subject to considerable uncertainty, they demonstrate the scale of the problem Portugal faces and the critical role that reforms to boost productivity and promote wage moderation must play in restoring competitiveness. 


\section{Box 2. Fund Policy Recommendations and Implementation}

The authorities' fiscal strategy emphasizes medium-term expenditure containment and sets a pace of adjustment in line with Fund policy advice. In recent years, the Fund has called for fiscal consolidation through structural expenditure measures, including civil service reform. In 2002-04, though, the government relied on substantial one-off measures to bring the deficit within SGP limits. In 2005, adjustment depended mostly on revenue measures, pending the implementation of planned spending reforms. Progress with Fund-advocated steps to strengthen budget planning and control and move toward comprehensive multiyear budget targets has been slow, although steps in this direction are under consideration.

The Fund has advocated structural reforms to strengthen the business environment and promote competition in product markets, as well as improved flexibility in labor markets. Steps have been taken to reduce red tape and improve the working of product markets. Measures to enhance labor market flexibility, though, have not been a high priority.

- $\quad$ Domestic demand, by contrast, is forecast to remain weak. Consumption growth is projected to slow, reflecting weak employment growth and necessary adjustments to household balance sheets: at end-2005, household debt was close to 120 percent of disposable income, more than double its level of eight years earlier and the secondhighest figure in the euro area. While some corporate balance sheet restructuring has occurred, still-high enterprise debt levels will retard investment, as well (Box 3). ${ }^{3}$ Fiscal adjustment will likewise weigh on domestic demand growth in the short term.

The staff sees a further strengthening of growth over the medium term, rising to about $2 \frac{1}{4}$ percent in 2009, still well below the 3 percent rate foreseen for that year in the authorities' December 2005 Stability Program update.

\footnotetext{
${ }^{3}$ See the accompanying Selected Issues Paper.
} 
Figure 6. Portugal: High Frequency Indicators
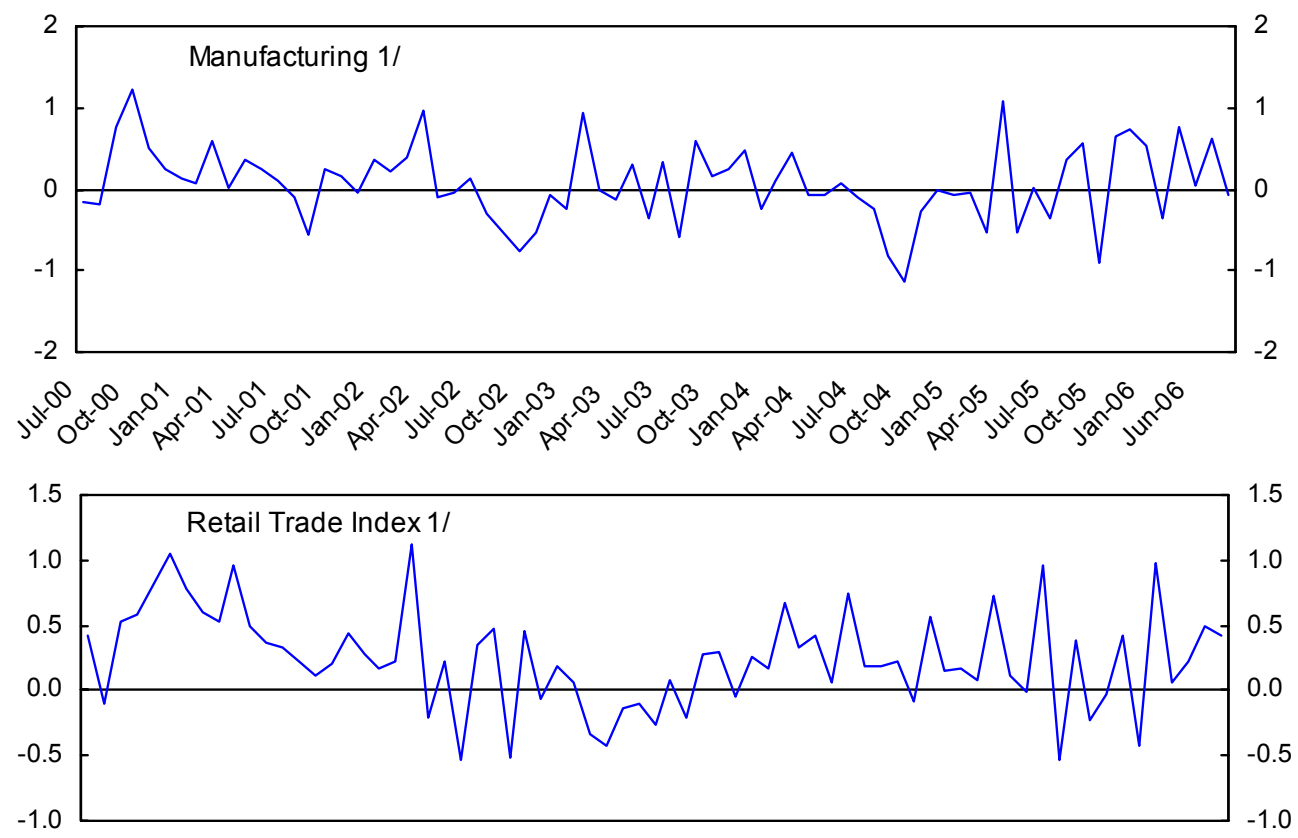

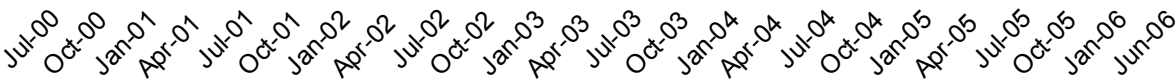

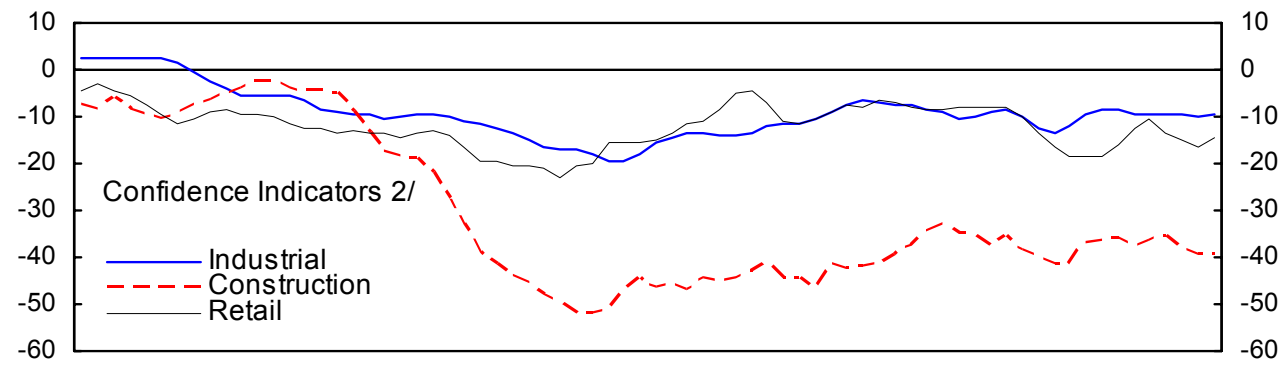

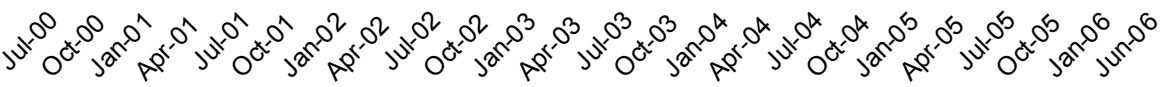

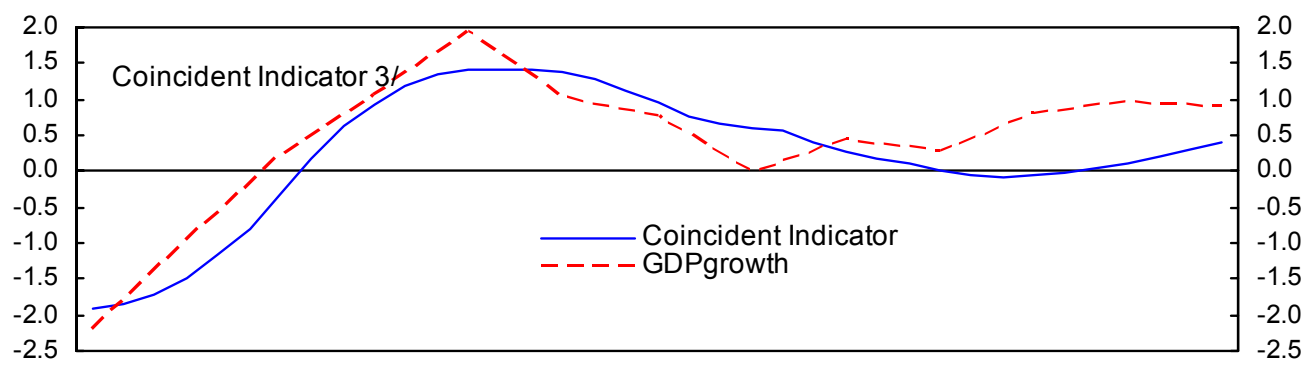

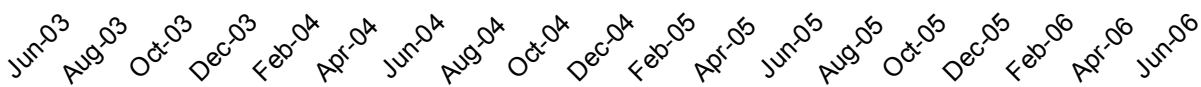

Source : INE, Bank of Portugal, IMF staff calculations, end of period.

1/ Seasonally-adjusted data, 6-month moving average on month-to-month growth, end of period. 2/3-month moving average, end of period.

3 / Year-on year growth rate (3-month moving average, seasonally adjusted). The coincident indicator is a composite indicator for economic activity published by the Bank of Portugal. It combines indicators of retail sales, heavy commercial vehicle sales, cement sales, manufacturing production, household's financial situation, new job vacancies, and a consumer survey of Portugal's main trade partners. 


\section{Box 3. Understanding Investment Behavior in Portugal}

Does the decline in corporate investment in Portugal reflect a more pessimistic private sector view of growth prospects, or high levels of indebtedness following the 1990s investment boom? Estimates using quarterly data from 1987 to 2005 suggest the answer is "both": investment reacts strongly to expected future output growth and is also negatively correlated with enterprises' lagged debt levels. Thus, while structural reforms to improve the fiscal environment and raise productivity-thus enhancing potential growth - should have a positive effect on private investment in the future, its recovery will be attenuated by the impact of still-high corporate debt. In this sense, the relatively inefficient corporate investment in the late 1990s could serve as a drag on growth prospects in the future.

6. Inflation in 2006-07 is forecast to remain stable. The inflationary effect of last year's 2 percentage point VAT rate increase is estimated at about $1 / 4$ to $1 / 2$ percentage point. With this effect fully incorporated in price data by the second half of the year, inflation is projected to recede to about $2 \frac{1}{2}$ percent by the end of this year and in 2007 . Nevertheless, the relatively high rate of price growth despite an output gap estimated by staff at about $13 / 4$ percent of potential output is suggestive of rigidities in product and labor markets that contribute to high costs of doing business and compromise competitiveness.

7. The external deficit is projected to continue widening. Notwithstanding the recent pickup in exports, the oil price-induced terms of trade loss and still-high imports would bring the deficit, excluding capital transfers, to about 10 percent of GDP this year and next. The deficit would continue to be financed by medium- and long-term bank borrowing. Under the staff's baseline scenario, the current account deficit would narrow to about $7 \frac{1}{2}$ percent of GDP by 2010 , bringing the net international investment position to a deficit of 88 percent of GDP (versus 66 percent in 2005). ${ }^{4}$ Portuguese firms have encountered no generalized difficulty in attracting external financing, which with the advent of the common currency now depends almost exclusively on individual firm solvency. Nevertheless, to the extent that the projected sizable external deficit should prove costly to finance, weaker consumption and investment than envisioned under the baseline scenario - and thus a slower recovery of medium term growth — would result.

\footnotetext{
${ }^{4}$ A 1 percentage point increase in interest rates would raise the current account deficit by about 1 percentage point of GDP and the external debt ratio by about 5 percent of GDP by 2010, according to staff simulations.
} 
8. The 2006 budget targets a reduction in the deficit to 4.6 percent of GDP, implying just over $1 \frac{1}{2}$ percentage points of structural adjustment this year. Revenue and expenditure forecasts in the budget were not updated to reflect the 2005 outturns and are therefore each understated by about 1 percent of GDP. A little more than half of this year's deficit reduction is to come from the full-year impact of revenue measures announced last year, in particular the VAT increase, with the balance coming mostly from savings in the public wage bill and intermediate consumption.

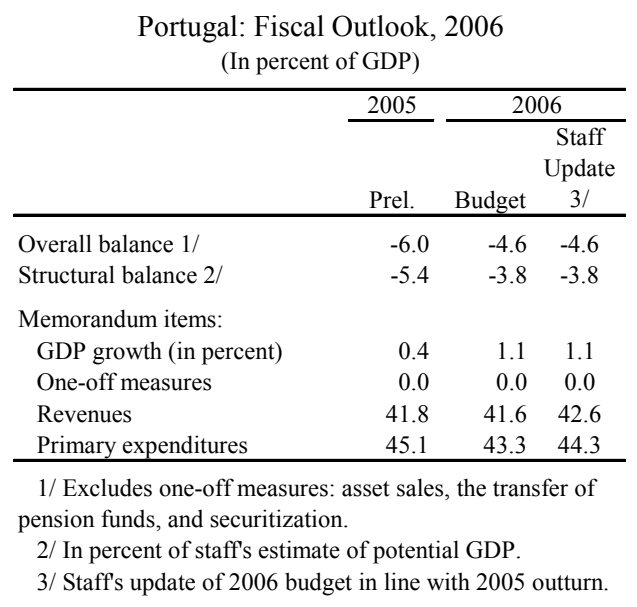

\section{REPORT ON THE DISCUSSIONS}

9. Discussions were marked by broad agreement on the challenges facing Portugal and most policy priorities to address them. It was well understood that Portugal required a fundamental transformation of its economy and its public sector, through reforms that would strengthen domestic competition, improve the business environment, increase government efficiency, and reduce the fiscal deficit through expenditure-based measures. However, proposed fiscal measures had provoked strong opposition from some interest groups, complicating their development and approval. The mission emphasized (especially in outreach efforts) that while even with full implementation of the reform agenda the economic environment was likely to remain difficult — and growth relatively slow - in the near term, slippages to the reform agenda would have a severe effect on the credibility of the adjustment effort, increasing its duration and costs. The mission also pressed the case for a fundamental labor market reform, which has had a low profile in the policy debate.

\section{The authorities recognized the complementarity of actions to address Portugal's}

challenges. High deficits and indebtedness divert resources from more productive uses, and preclude desirable reductions in marginal tax rates (see $\$ 14$.) They also contribute to uncertainty about future fiscal policy, further discouraging investment. And, of course, faster growth would facilitate more rapid deficit reduction. Beyond this, the mission noted, a history of high tax evasion has introduced distortions that lead to inefficient business decisions; excessive bureaucracy has discouraged investment; and problems with the education and training system have contributed to generally low levels of human capital. Thus, ongoing reforms to create a more dynamic and efficient public sector could boost private sector competitiveness through several channels. The authorities were therefore hopeful that a combination of fiscal adjustment and structural reforms to stimulate innovation and investment could lead to a virtuous cycle of mutually reinforcing output growth and budget consolidation in the medium-term. 


\section{A. Fiscal Policy}

11. The authorities and staff agreed that achievement of the 2006 deficit target was crucial to maintaining public confidence in the fiscal program, but differed in their view of the risks to the outcome. The authorities noted that revenue performance thus far had been strong, owing in part to enhancements in tax administration such as increased computerization and improved cross-checking among the internal revenue service and the customs and social security authorities. They also observed that spending at the state level through midyear suggested that budget execution was broadly on track. Thus, while the mission pointed to risks - including higher spending on social transfers and health care, and by local governments and autonomous funds - that could together add nearly $1 / 2$ percent of GDP to this year's deficit, the authorities were confident that their target of 4.6 percent of GDP would be achieved. Nevertheless, they would take additional spending measures if necessary.

\section{The authorities highlighted recent strides in the development of the bedrock} structural reforms that are to underpin medium-term consolidation (Box 4). While adjustment in 2005-06 had focused primarily on revenue measures, over the coming years reforms to the civil service, to the structure of the public sector, and to the social security system for private sector workers would shift the balance of the effort to the spending side and address the root cause of current fiscal weaknesses: the steady rise of spending on pensions and wages over the last decade.

Implementation of these measures was therefore fundamental to reducing the budget deficit to 3.7 percent of GDP next year and to below 3 percent of GDP by 2008, in line with EDP commitments.

Portugal: Growth and Composition of Current Primary Spending 1995-2005 (In percent of GDP)

\begin{tabular}{lrrr}
\hline & 1995 & 2005 & Change \\
\hline Current expenditure & 39.8 & 43.4 & 3.6 \\
Interest payments & 6.3 & 2.8 & -3.5 \\
Primary current expenditure & 33.5 & 40.6 & 7.1 \\
o.w. wages and salaries & 13.6 & 14.7 & 1.1 \\
Social Transfers & 13.2 & 18.2 & 5.0 \\
Subsidies & 1.3 & 1.6 & 0.3 \\
Other & 5.4 & 6.1 & 0.7 \\
\hline
\end{tabular}

1/ Stability and Growth Program; 2006 Budget, and Fund staff calculations.

After delays, important progress had been made on some initiatives: Parliament had approved the civil service reform in July, and the government had agreed with the social partners on the outlines of the social security reform that same month. The authorities planned to submit this latter measure to Parliament by September. Steps were also underway to improve the efficiency of spending on health and education, and to modify the system of local government financing to reduce a bias to spend in existing arrangements.

\section{The authorities expected the impact of these measures to be incorporated in the} $\mathbf{2 0 0 7}$ budget but acknowledged that the yield of some was difficult to forecast. Fiscal benefits from the planned social security reform will rise over time, but some savings should be realized even in 2007, primarily through changes in early retirement rules and the indexation of benefits. The yield from the civil service reform and restructuring of the public 


\section{Box 4. Structural Fiscal Reforms}

- $\quad$ The reform of the social security system for private sector workers follows last year's reform of the system for civil servants. Benefits will be indexed to the inflation rate (though relatively low pensions will enjoy a small real increase when output growth is above 2 percent and higher pensions will suffer a small real decline when growth is below that threshold), an explicit link between benefits and changes in life expectancy will be introduced, the alreadyscheduled shift in the reference period for calculating pensions to encompass a worker's entire career will be accelerated, and disincentives for early retirement will be increased.

- $\quad$ The reform of the civil service aims to reduce the number of career paths and increase flexibility within public employment. The reform will allow excess workers to be transferred to a pool where they will receive reduced benefits and salaries as an inducement to leave public employment. At the same time, the government intends to continue replacing only half of all retiring civil servants.

- The reorganization of the public sector ("PRACE") seeks to reduce the number of administrative structures and streamline procedures. In concert with the reform of the civil service, it should generate an increase in labor mobility within the public sector, a reduction in the wage bill, and, over time, a decline in employment.

- $\quad$ Reforms of health and education spending and changes to the system of financing local governments are ongoing or planned. Hospitals will continue being converted into public corporate entities, hopefully improving management practices. Steps have been taken to reduce spending on pharmaceuticals and increase copayments for medicines. The government also envisages efficiency gains through changes in the school network and the consolidation of small schools. Municipal governments will be given flexibility to alter tax rates, complementing recent measures that introduced more comprehensive limits on indebtedness and improved reporting requirements.

sector was harder to project, however. There was no doubt that Portugal's public sector is substantially overstaffed. If implemented effectively, these initiatives therefore had the potential both to increase efficiency - by making it easier to shift public employees across sectors as needed - and to generate significant savings, as some workers would be moved to an excess labor pool where they would receive reduced wages and benefits as an inducement to leave public employment. However, decisions on staffing levels would be made primarily 
at the unit level, and the authorities understood that inducements for managers to rationalize staffing might be necessary. The mission encouraged the authorities to base the 2007 budget on conservative estimates of the yield of these reforms, supplementing them with additional high-quality spending measures as needed. Continued progress in reducing the deficit in line with the EDP commitments was jointly seen as essential to maintain confidence in the adjustment program and minimize the short-term output costs of fiscal consolidation.

\section{Institutional reforms to further strengthen medium-term fiscal performance} were also under consideration. The authorities concurred with the fiscal ROSC's suggestion that a binding multiyear budget framework with explicit expenditure ceilings for outer years would improve budget execution by providing spending units with a clearer indication of the future resources available to them. A pilot program along these lines might be introduced in 2009. Consideration was also being given to revenue-neutral simplification of the tax code, for example eliminating intermediate VAT rates for some goods and lowering the maximum rate, or further phasing out income tax benefits and cutting marginal rates. These measures would decrease the cost of compliance with the system, facilitate administration, and reduce distortions. Given the risk of unanticipated revenue effects, however, a reform would likely await a further strengthening of the fiscal position.

\section{It was agreed that additional fiscal adjustment would be needed beyond 2008 to} ensure long-term sustainability and to allow fiscal stabilizers to operate. Forecasts of aging-related spending, including recently by the EC, point to large increases in pension and health expenditure in the coming years. Staff simulations show that without additional deficit reduction beyond 2009, the public debt would rise sharply over the medium term. Preliminary calculations based on updated projections for long-term health and pension spending that take account of the pending pension reform, and on realistic forecasts for output growth, suggest that long-run debt sustainability would require a budget surplus of at least $1 / 2$ percent of GDP by 2013 (Box 5) implying an additional 2 percentage points of GDP of fiscal adjustment after 2009. The authorities' official medium-term objective calls for a structural deficit of " $1 / 2$ percent of GDP or less," which they and staff agreed would allow full operation of automatic stabilizers over the cycle without violating the Stability Pact's 3 percent of GDP deficit ceiling. They agreed that the adequacy of any medium- to long-term target would need to be re-evaluated periodically in light of developments with output and health and pension spending.

\section{B. Revitalizing Growth and Restoring Competitiveness}

\section{The government's Technological Plan is central to its program to raise}

productivity growth. The plan seeks to address Portugal's very low R\&D and IT spending (Figure 7), including by providing fiscal incentives for investment, promoting training, and 


\section{Box 5. Fiscal Sustainability}

Staff's baseline scenario incorporates the adjustment path in the authorities' Stability Program Update, with the deficit reduced to 1.5 percent of GDP by 2009, and keeps revenue and non-age-related spending ratios to GDP constant thereafter, with no subsequent fiscal adjustment. Under this scenario, the debt ratio would reach some 100 percent of GDP around 2025 and would continue to rise thereafter.

An alternative scenario takes into account the effect on long-term pension spending of the proposed pension reform and assumes a budget surplus of some $1 / 2$ percent of GDP is achieved by 2013, following which non-age-related spending is kept constant as a percentage of GDP. Under this scenario, the debt ratio would remain broadly stable (and just below the 60 percent of GDP SGP ceiling) over the next four decades.

Portugal: Long-Term Aging-Related Fiscal Projections, 2000-50 (In percent of GDP)
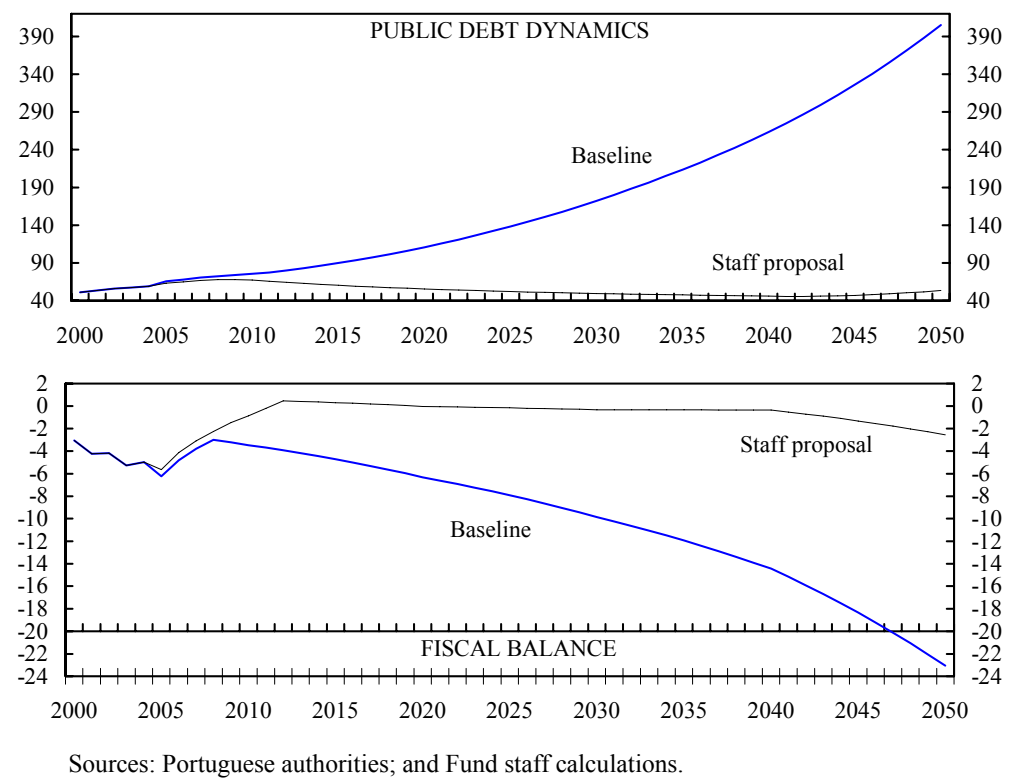

encouraging contacts between firms and universities. The authorities saw these measures as essential to address market failures, among them the difficulty that small- and medium-sized enterprises face in financing technological investments, and the generally low levels of human capital among workers and managers. 
Figure 7. Portugal: Structural Indicators
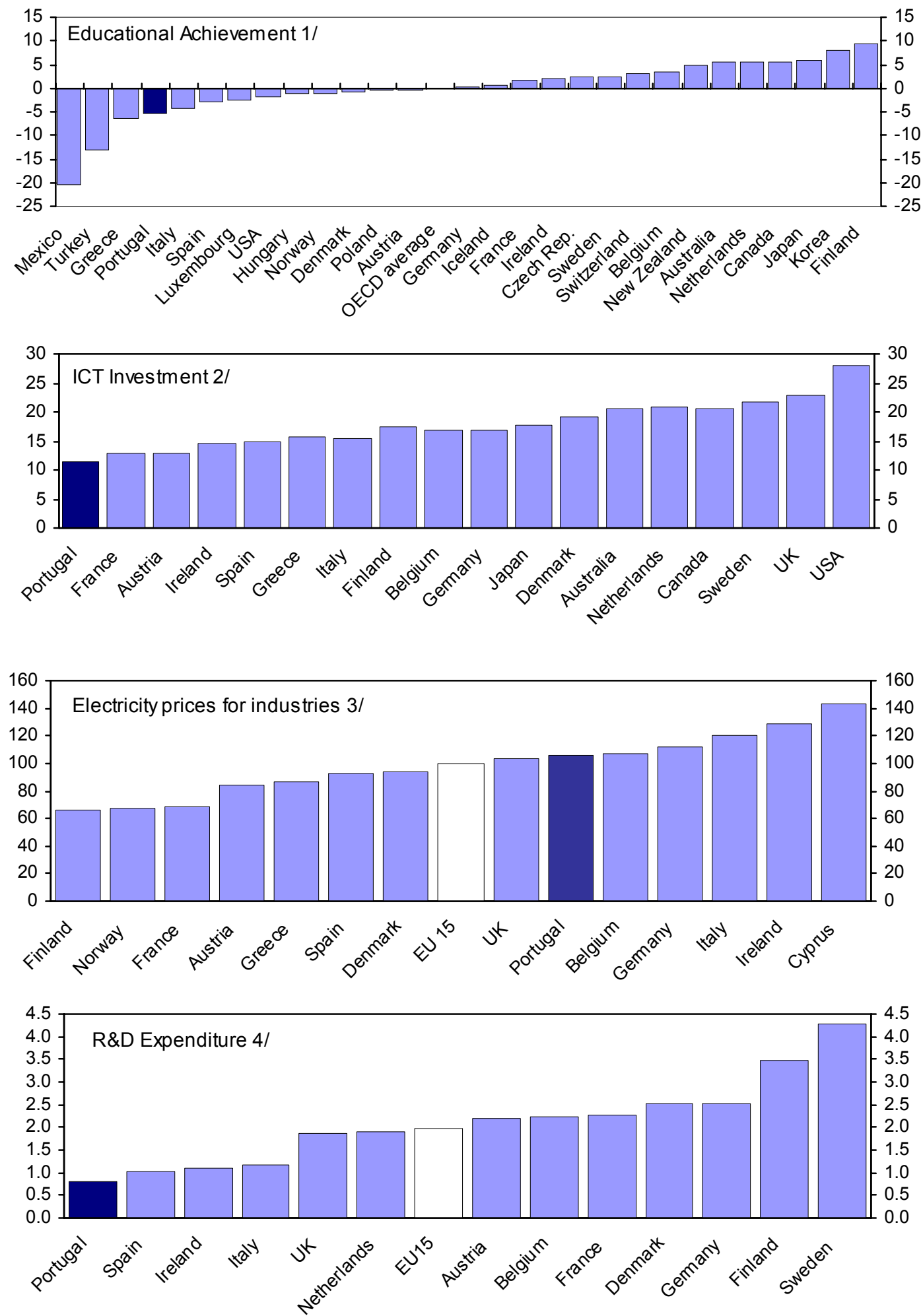

Source: OECD, EUROSTAT; Fund staff calculations.

1/ Average of PISA scores in reading, mathematics and science, 2003.

2/ Percent of non-residential gross fixed capital formation, total economy, 2001.

3/ Index EU15=100, 2006 (1st half).

4/ In percentage of GDP, 2002 
17. Efforts to reduce bureaucratic impediments to investment are also a key element of the authorities' program. The authorities observed that different global indices of the business environment - for example, the World Bank's Doing Business Indicators and the World Economic Forum's Global Competitiveness Index - tended to give contrasting, and insufficiently nuanced, views of the overall investment climate. As such, they cautioned against relying on any single measure or set of measures when assessing the business environment. Nevertheless, they recognized that there was scope for improvement and noted the important progress already made. Bureaucratic requirements have been streamlined under the SIMPLEX program, eliminating numerous barriers to investment and accelerating the process of opening new firms and registering trademarks. Thus far, the effort to reduce red tape had not been prioritized, in the hope that eliminating a large number of bureaucratic requirements in the first year would raise awareness of, and generate momentum for, the new program. The mission supported the plan to adopt a more targeted approach to SIMPLEX next year, focusing on licensing requirements, which private investors consider to be especially burdensome in Portugal. Steps were also underway to accelerate the legal system, although separation of powers provisions limit the government's freedom of action. As improvements to the business environment would benefit firms throughout the economy, the mission believed they could have a bigger impact on productivity than would the more targeted initiatives under the Technological Plan. In any case, reforms to the investment climate would leverage the effects of the Technological Plan.

\section{The authorities agreed that greater competition and efficiency in domestic} markets was also critical to enhancing productivity. Increased competition in key network sectors - including telecommunications, electricity, and natural gas - was in the offing, with potentially important effects on production costs economy-wide. Steps had been taken to enhance competition in electricity generation, although the immediate impact on energy prices would be reduced by the decision to pass on to consumers the costs arising from existing long-term electricity supply contracts with producers (PPAs) and by the policy to increase the share of renewables in generation. Preparations were also underway for a gradual opening of the domestic gas market next year. Action by the Competition Authority had led to the elimination of minimum fees for some professions and had reduced barriers to entry in a number of retail sectors (e.g., pharmacies and gas stations).

\section{The privatization process has been reinvigorated, with the objective of reducing} the role of the state in the economy and enhancing efficiency. The authorities target sales of equity stakes worth some $€ 3.7$ billion through 2009 ( $€ 1.6$ billion in 2006), with at least 80 percent of proceeds going to reduce debt. ${ }^{5}$ Assets in the energy and paper sectors could be sold this year, and the authorities also expected to initiate the privatization processes for the

\footnotetext{
${ }^{5}$ Any balance would go toward recapitalizing public enterprises or compensating former owners of nationalized assets, as required by law.
} 
national airline, TAP, and the airports authority. They did not, however, foresee a privatization of Caixa Geral de Depósitos, a fully state-owned financial entity that accounts for some 25 percent of banking system assets. The FSAP mission had suggested that the authorities consider whether, over the longer run, financial market globalization and deregulation implied that full state ownership of the entity might no longer be the most effective means of achieving their policy objectives. The authorities stated, however, that so long as CGD operated as a commercial entity subject to the same regulatory framework as its private competitors, they saw no compelling reason to change its ownership structure. (See below for further details on the FSAP findings and recommendations).

20. As in previous consultations, there was disagreement over the priority due labor market liberalization. The authorities highlighted recent changes to the unemployment compensation system that broaden the definition of "acceptable employment," promote more active job-seeking by the unemployed, and link the duration of an individual's benefits to the length of his contribution period. These changes, undertaken jointly with plans to strengthen coordination between the social protection system and the education and training network (in line with OECD recommendations), are expected to speed the reintegration of the jobless into employment. The authorities argued that international indicators that point to high employment protection in Portugal (Figure 8) are misleading, failing to recognize that firms typically use negotiated severance packages to shed labor rather than rely on admittedly cumbersome legal procedures, and discounting the extensive use of short-term contracts and self-employment. The mission noted, however, that recent steps to limit reliance on negotiated dismissals - to reduce their budgetary costs - would effectively make prevailing employment protection legislation more binding, increasing the need for its overhaul. It also argued that firms' preferences for short-term contracts and self-employment are symptoms of - not cures for-excessive employment protection, and contribute to inequities and to low levels of training while slowing the movement of labor across sectors. Changes are also needed to collective bargaining provisions, the mission argued, to allow greater flexibility at the firm level. More generally, the mission stressed that labor market reforms would contribute to reducing unit labor cost growth from both the wage and productivity sides and should therefore be a critical component of the strategy to strengthen competitiveness.

\section{Financial Sector Issues}

21. The FSAP found that Portugal's financial system is generally sound (see the FSSA and Box 6). The system has weathered the weak macroeconomic environment of recent years relatively well. Banks have diversified income sources, rationalized operating 
Figure 8. Portugal: Employment Protection Legislation (EPL) Strictness Indicators, 2003
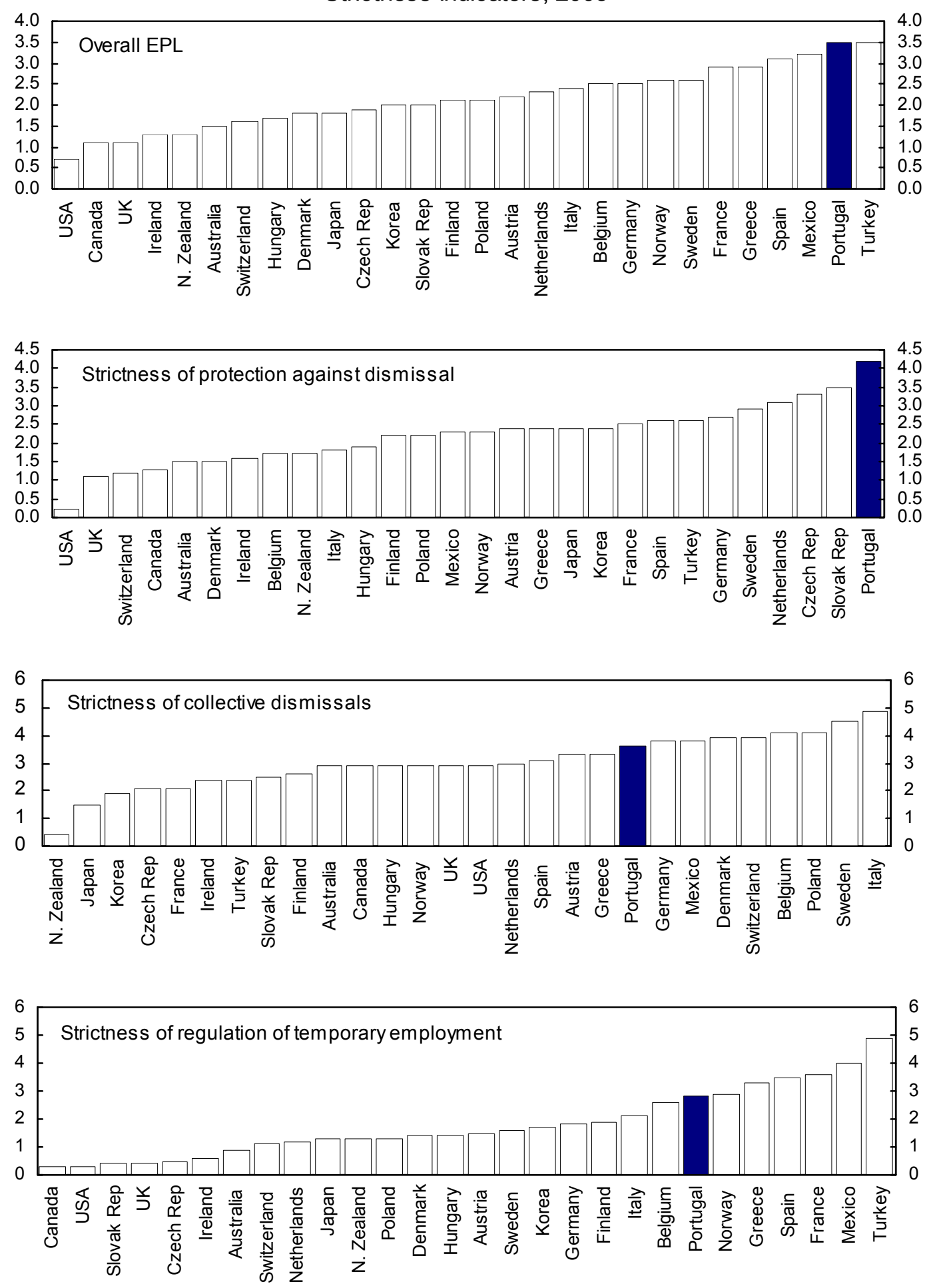

Source: OECD Employment Outlook 2004 
Figure 9. Portugal: Credit and Asset Market Developments, 2000-05
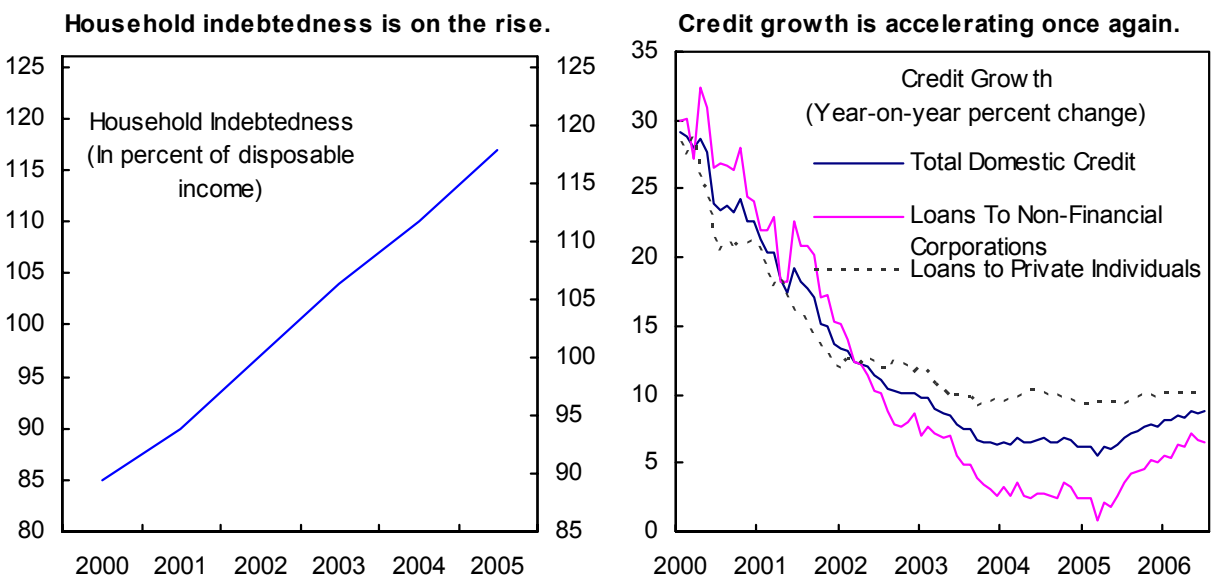

Credit to the private sector exceeds the EU average by a wide margin...
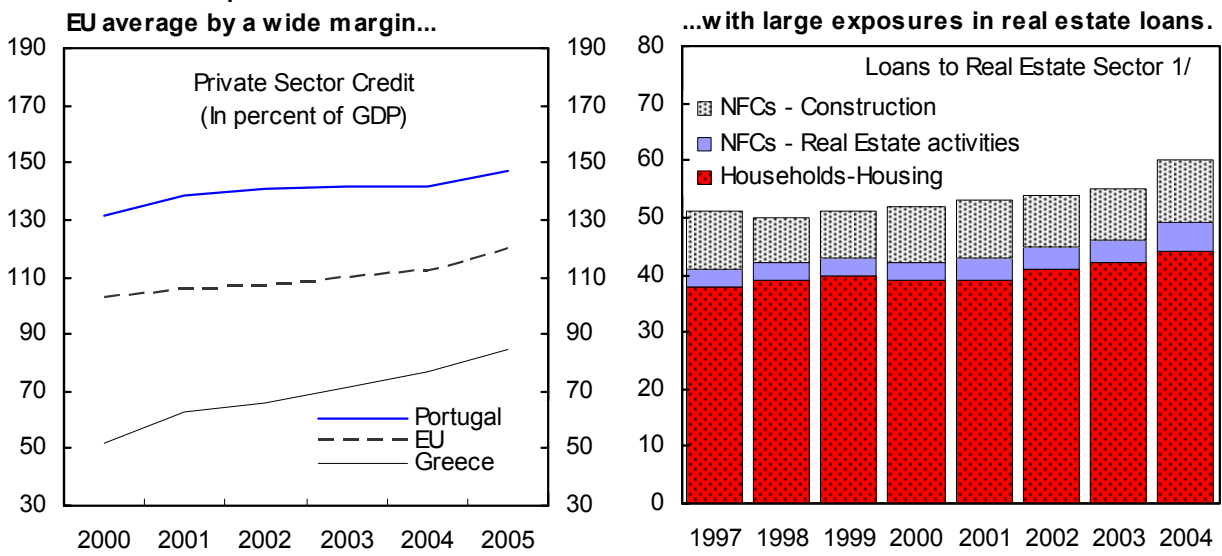

Property prices have been broadly stable.
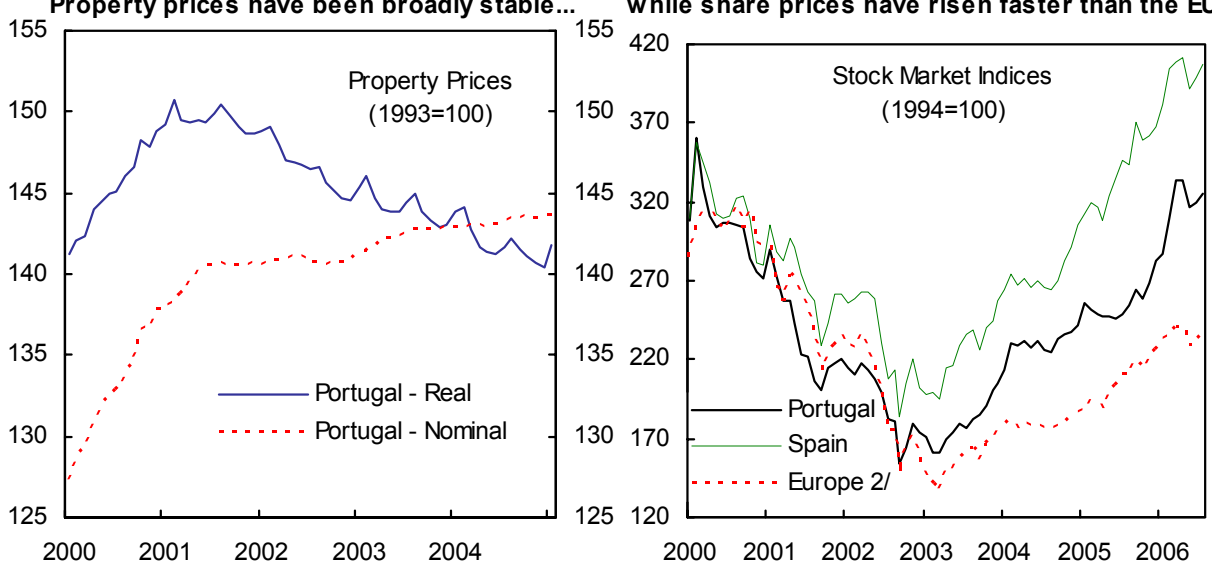

Source: Bank of Portugal; Ministry of Finance, Monthly Economic Indicators; Datastream; and Fund staff calculations.

$1 /$ Loans to non-financial corporations of the construction and real estate sectors and to households for housing as a percentage of total loans extended to the non-financial private sector (adjusted for securitization).

2/ FTSE Eurotop 100 (in euros). 


\section{Box 6. Main Findings of the FSAP}

- $\quad$ Portugal's financial system is sound, well managed, and competitive. Shortterm vulnerabilities appear well contained, as confirmed by stress test results, although banks are sensitive to equity market risk through their employee pension funds. Over the medium term, rising household and corporate sector debt and significant concentration of banks' exposure across sectors (especially real estate) and borrowers may represent important potential risk factors, especially if economic conditions remain sluggish, and will need to be monitored closely. Potential domestic channels for contagion risk and crosssectoral spillovers among banks appear quite low.

- The supervision of banks' loan classification and provisioning policies - an area which raised some controversy a few years ago - was assessed to be in full compliance with international best practices, following some regulatory changes in 2002-03.

- In the last few years, the performance and soundness of the insurance sector has strengthened. While relatively sensitive to various types of market and underwriting risks, the insurance sector seems able to withstand a number of severe shocks, though the impact on individual insurers varies widely.

- $\quad$ The infrastructure for the settlement of payments and securities transactions is highly developed, efficient, technologically well advanced and-from a risk management perspective - robust. Supervision of financial institutions as well as of payments and settlement systems is professional and active, comparing very well with international standards. The financial autonomy of the insurance and securities supervisors should be more formally safeguarded, while the former agency should shed, over time, some nonsupervisory functions.

costs, and enhanced risk management procedures. Portugal's banking sector compares favorably with those of other EU countries in terms of asset quality, efficiency, and profitability, while capital adequacy is about average. The financial soundness of the insurance sector has improved, reflecting a deepening of the market, better alignment of premiums to risk in some categories, positive investment yields, and reduced personnel costs.

22. Risks arise mainly from high household and corporate debt. Lending to households - especially mortgages for owner-occupied housing — has expanded rapidly, bringing the private sector credit-to-GDP ratio to about 150 percent, the highest value in the EU. Household mortgages are typically at floating rates. Loan-to-value ratios have risen as a result of greater competition among banks, but there is no evidence of real estate 
overvaluation. The authorities noted that owing to low interest rates and the lengthening of mortgage maturities, the debt service burden for households has remained moderate. They also emphasized that high indebtedness reflects in large part improved access to mortgage credit by households, as well as inefficient rent control laws that constrain the development of a rental market for housing. Other risks to the financial system include the concentration of bank lending to a limited number of large corporates (albeit within supervisory limits), and the exposure of banks' employee pension schemes to the stock market.

\section{The FSAP considered these risks to be manageable, though worthy of continued} close monitoring. Stress tests showed that the capacity of the financial system to absorb even severe disturbances to the macroeconomic environment is strong, given comfortable profitability and solvency buffers. The overall prudential regulatory framework is sound, and the supervision of financial institutions and payments and settlement systems is professional and active, comparing very well with international standards. Nevertheless, a number of specific issues within the financial system merit attention, including the needs to consider additional capital requirements for mortgages under Basel II, and to continue encouraging banks to refine systems to measure and control risks.

\section{The authorities broadly agreed with the FSAP analysis and recommendations,} which - it was recognized-were primarily technical in nature. In particular, the insurance and stock market supervisors welcomed the call for greater financial autonomy. The Bank of Portugal noted that banks have made considerable strides in assessing credit risks in recent years, and that this process would continue as they adjusted to new requirements under Basel II. More generally, the Bank saw many of the FSAP recommendations as supportive of ongoing initiatives or strands of work, such as the full implementation by the Bank of a comprehensive risk rating system for supervised credit institutions. The authorities welcomed the generally positive assessment of compliance with core principles but felt that in some cases the assessment did not take adequate account of measures already in place or under development (see also paragraph 19 of this staff report regarding the authorities' views on state ownership in the banking system.)

\section{Other Issues}

25. The quality of statistical data has improved (Appendix II). Notably, the reporting of fiscal data during the year has become more comprehensive, permitting a better intra-year evaluation of budget execution. The authorities have completed the rebasing of national accounts data to 2000 .

\section{Staff Appraisal}

26. Recent months have witnessed important progress in the economic and policy environment, but the challenges that Portugal confronts remain considerable. A modest recovery of output is underway, thanks in part to solid export growth in the first half of the year. In addition, some significant structural reforms have been introduced, while others have 
moved closer to fruition. Nevertheless, reducing large fiscal imbalances and restoring external competitiveness will be a lengthy and difficult process. Fortunately, there are important complementarities between these goals, raising the prospect that successes in each area could generate a virtuous cycle of faster growth and adjustment in the medium term.

27. The authorities' strategy to meet these challenges is generally sound, but firm implementation is essential to its success. The commitment to bring the fiscal deficit below 3 percent of GDP without one-off measures by 2008 primarily by tackling the public wage bill and pension spending is wholly appropriate. The growth of these spending categories over the last decade is a prime cause of the current high deficit. Moreover, international experience shows that expenditure-based fiscal adjustments tend to be more durable and effective than revenue-based ones. To maximize the credibility of the adjustment effort, planned reforms to the civil service, to the structure of the public sector, and to the social security system for private sector workers must be introduced without delay and implemented rigorously. Likewise, improvements to the business environment and increased domestic competition offer the prospect of enhancing Portugal's medium-term growth potential, and progress in this area should continue. Slippages in the reform agendaespecially on fiscal measures - would only damage confidence and increase the duration and costs of adjustment.

28. Achieving the $\mathbf{2 0 0 6}$ deficit target is fundamental to ensuring the credibility of the adjustment effort, and the authorities' commitment to reinforce budget measures if necessary is therefore welcome. Risks of spending overruns on social transfers and health care, and by local governments and autonomous funds, call for careful monitoring of budget execution and tight control of spending. Given the predominant role that revenue measures have played in deficit reduction so far-including in 2006, when the full-year effect of last year's VAT increase will make an important contribution to revenue growth - any additional measures should operate on the expenditure side.

\section{For 2007-09, it will be essential that expenditure measures move to the} forefront, realizing the planned shift away from revenue-based adjustment. The authorities anticipate that the public sector, civil service, and private sector pension reforms should contribute to this goal starting next year. In light of uncertainties regarding their yield, however, the 2007 budget should be based on conservative estimates of their impact, with additional specific spending measures incorporated as needed to achieve the deficit target. The authorities should ensure that adequate incentives are in place to induce unit managers to maximize staffing efficiency under the civil service and public sector reforms. Steps to increase the effectiveness of spending on health and education should also continue to be implemented, with a view to reducing inputs and improving the quality of outputs from the school and healthcare systems. The pending reform of local government finances will address incentives to spend under current arrangements, and should — along with the more 
comprehensive limits on indebtedness and reporting requirements already implementedimprove medium-term fiscal discipline.

30. Even with the implementation of recent and planned pension reforms, fiscal adjustment will be needed after 2009 to ensure long-term sustainability. In light of projected future increases in aging-related spending, the authorities should commit to a path of further deficit reduction that would yield a fiscal position consistent with long-run debt sustainability by 2013. Provisional calculations suggest a surplus of $1 / 2$ percent of GDP will be required, though the adequacy of any target will need to be re-evaluated periodically in light of developments with output and health and pension spending.

\section{A credible deficit reduction strategy is essential to raise potential growth but}

cannot do so alone. Reforms to strengthen the business environment and increase domestic competition are also critical to restarting income convergence. Measures to remove bureaucratic and regulatory impediments are a highly cost-effective means of promoting private investment and growth and will reinforce the effectiveness of the Technological Plan. The intention to focus attention on easing licensing requirements is welcome. Within the constraints imposed by the constitution, the authorities should continue to promote efforts to accelerate legal processes. Increased domestic competition would boost the competitiveness of Portuguese enterprises by reducing prices and promoting innovation and investment, and work by the government and the Competition Authority in this area should proceed apace. Faster growth is a virtue itself, but given the complementarities between output growth and deficit reduction, a failure to make progress with growth-enhancing reforms could complicate the achievement of the medium-term deficit targets, undermining confidence in the authorities' overall policy package. This is especially a concern given that the mediumterm growth projections in the authorities' Stability Program Update significantly exceed the staff's.

32. In this respect, fundamental labor market reform should be a high priority. Strong nominal wage growth even in the face of increases in the unemployment rate, high rates of long-term unemployment, and heavy reliance on fixed term-contracts and selfemployment all testify to the presence of significant rigidities in labor markets. These rigidities slow the movement of labor to fast-growing sectors, discourage investment in worker training, inhibit the adjustment of wages to market conditions, and raise serious equity concerns by contributing to a dual labor market. Measures to increase labor market flexibility, along with adjustments to collective bargaining provisions to allow greater responsiveness to individual firm conditions, are critical to raise productivity and promote wage moderation, thereby strengthening the competitive position. Recent changes to the unemployment compensation system are welcome but are not a substitute for these reforms.

\section{The financial system is sound and well supervised, but the authorities should} continue to monitor risks closely. The relatively high levels of household and corporate debt, the concentration of bank lending to the real estate sector and to a limited number of 
large corporates, and the exposure of banks' employee pension schemes to the stock market call for continuous vigilance. The FSAP finding that comfortable profitability and solvency buffers are capable of absorbing even severe disturbances to the macroeconomic environment is reassuring. However, as the financial system evolves, the authorities should reassess periodically its capacity to respond to shocks. The authorities are encouraged to implement the FSAP recommendations.

34. Portugal is encouraged to increase its ODA to the 0.7 percent of GNI benchmark.

35. It is proposed that the next Article IV consultation be held on the standard 12-month cycle. 
Table 1. Portugal: Selected Economic Indicators, 2001-07

(Changes in percent, except as otherwise indicated)

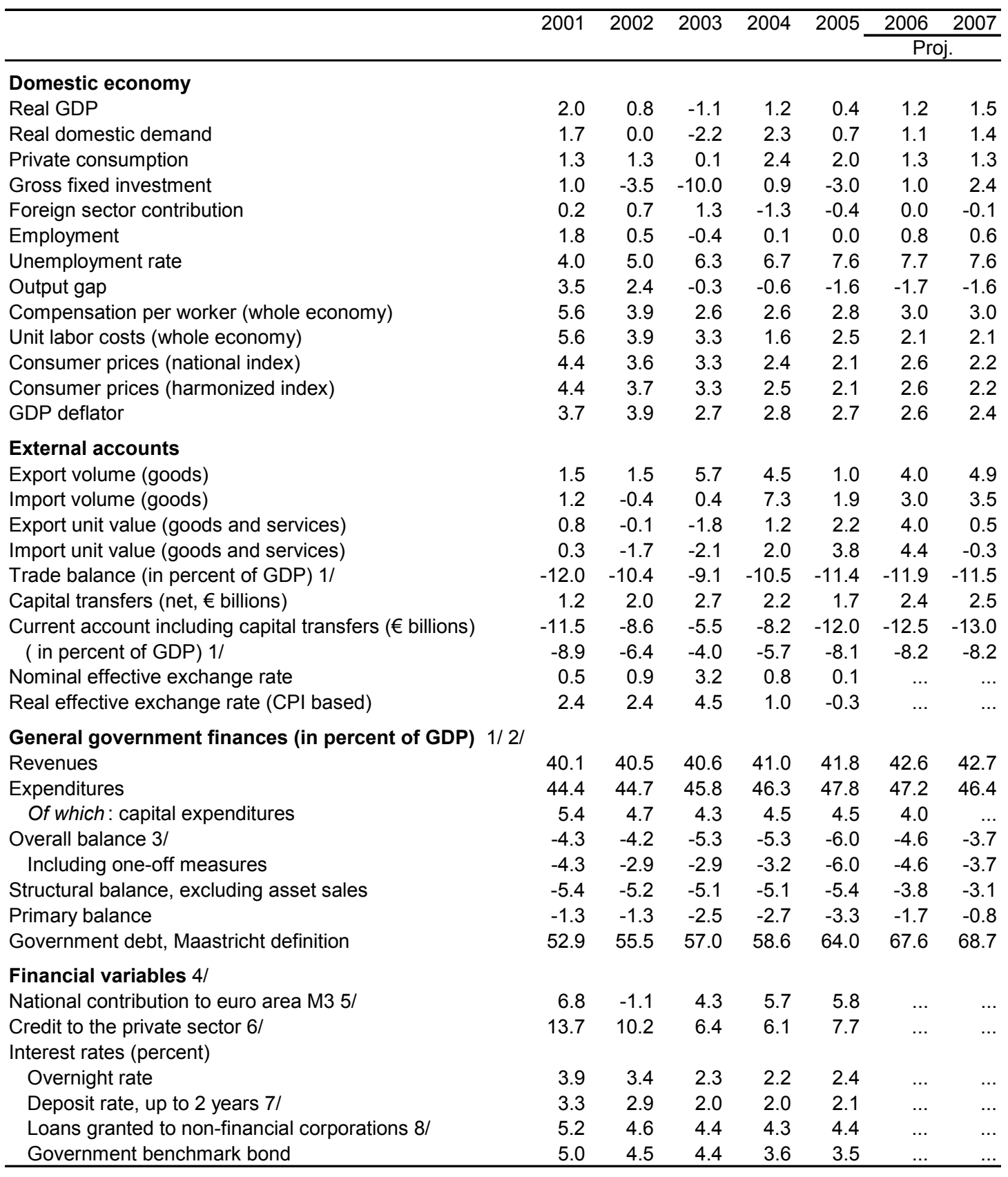

Sources: Bank of Portugal; Ministry of Finance; National Statistics Office (INE); and Fund staff estimates and projections.

1/ GDP ratios use revised GDP series with base year 2000.

2/ Asset sales, including UMTS receipts, the transfer of the postal pension fund and securitization are netted out for purposes of calculating structural balances.

3/ Excludes one-off measures.

4/ End-of-period data.

5/ Excludes the currency in circulation held by non-bank private sector.

6/ Includes securitized loans. 2001 onwards it is also corrected for loan write-offs and reclassifications.

7/ Data refer to new deposits before 2003 and to the stock of outstanding deposits thereafter. Before

2003 deposit rate with 91-180 days maturity.

$8 /$ Average rates on outstanding amounts of loans, denominated in euros to residents in the euro area, for each sector and/or purpose, weighted by the corresponding outstanding amounts at the end of the month in each original maturity. Before 2003 lending rate with 91-180 days maturity. 
Table 2. Portugal: Balance of Payments, 2000-10

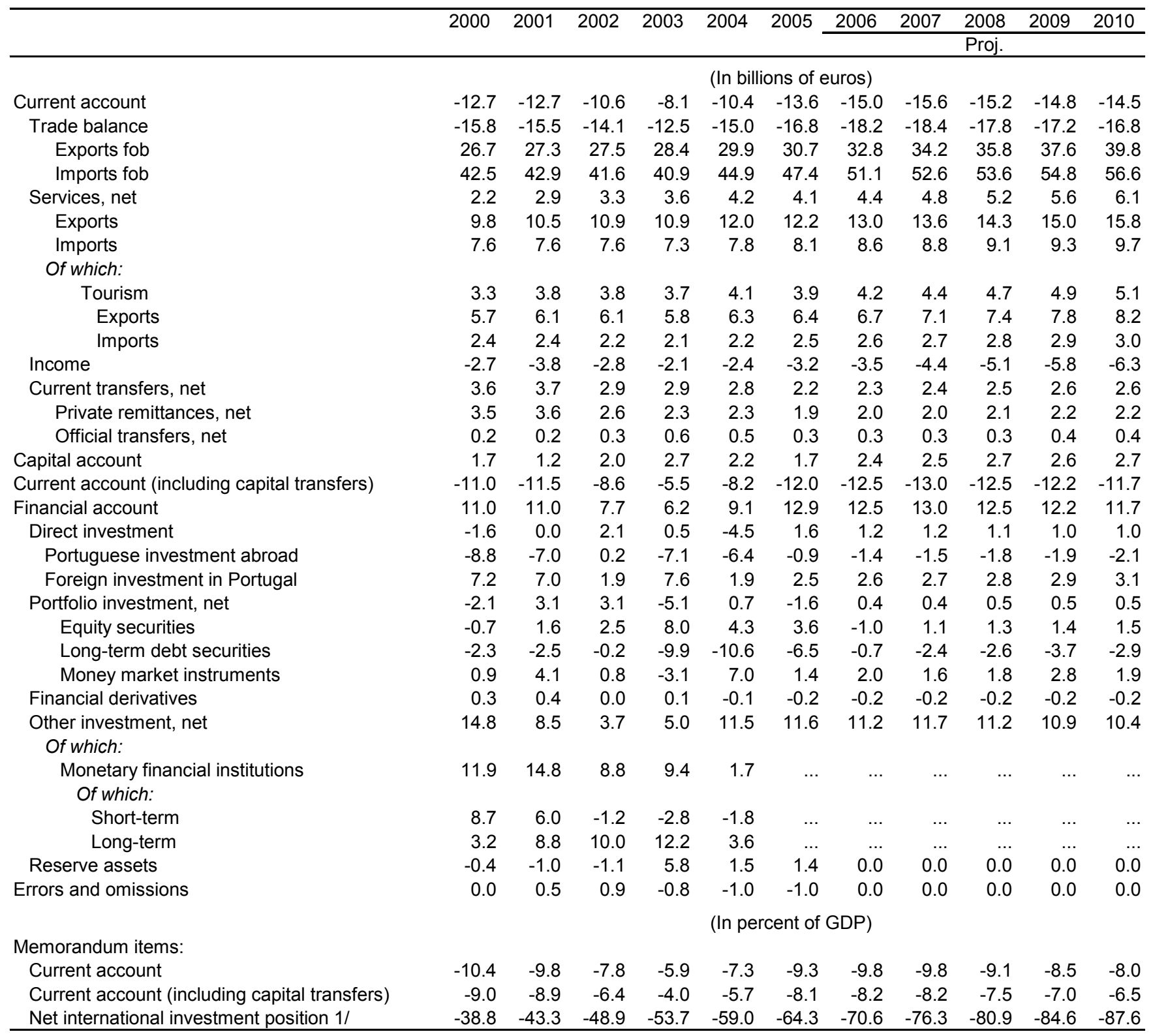

Sources: Bank of Portugal; and Fund staff calculations.

1/ End-of-period data. 
Table 3. Portugal: General Government Accounts, 2000-06

\begin{tabular}{|c|c|c|c|c|c|c|c|}
\hline & 2000 & 2001 & 2002 & 2003 & 2004 & 2005 & $20061 /$ \\
\hline & \multicolumn{7}{|c|}{ (In millions of euros) } \\
\hline Total revenues & 49,114 & 51,845 & 54,863 & 55,768 & 58,628 & 61,582 & 63,653 \\
\hline Current receipts & 47,457 & 49,665 & 52,525 & 53,286 & 56,602 & 59,564 & 61,499 \\
\hline Tax revenue & 28,506 & 29,599 & 30,771 & 30,754 & 32,824 & 35,204 & 37,138 \\
\hline Social security contributions & 13,682 & 14,738 & 15,729 & 16,562 & 17,692 & 18,341 & 18,324 \\
\hline Other current revenues & 5,269 & 5,328 & 6,025 & 5,970 & 6,086 & 6,018 & 6,037 \\
\hline Capital revenue & 1,657 & 2,180 & 2,338 & 2,482 & 2,026 & 2,018 & 2,154 \\
\hline Total expenditures & 53,058 & 57,358 & 60,549 & 63,025 & 66,245 & 70,449 & 70,622 \\
\hline Primary current expenditures & 42,999 & 46,576 & 50,248 & 53,359 & 55,997 & 59,789 & 60,143 \\
\hline Interest payments & 3,655 & 3,851 & 3,868 & 3,775 & 3,785 & 4,019 & 4,392 \\
\hline Capital expenditures & 6,404 & 6,931 & 6,433 & 5,892 & 6,463 & 6,641 & 6,087 \\
\hline Overall balance 2/ 3/ & $-3,944$ & $-5,513$ & $-5,686$ & $-7,257$ & $-7,617$ & $-8,867$ & $-6,969$ \\
\hline \multirow[t]{2}{*}{ Including one-off measures } & $-3,545$ & $-5,513$ & $-3,864$ & $-4,000$ & $-4,566$ & $-8,867$ & $-6,969$ \\
\hline & \multicolumn{7}{|c|}{ (In percent of GDP) 2/ } \\
\hline Total revenues & 40.2 & 40.1 & 40.5 & 40.6 & 41.0 & 41.8 & 41.6 \\
\hline Current receipts & 38.8 & 38.4 & 38.8 & 38.7 & 39.6 & 40.4 & 40.2 \\
\hline Tax revenues & 23.3 & 22.9 & 22.7 & 22.4 & 22.9 & 23.9 & 24.3 \\
\hline Social security contributions & 11.2 & 11.4 & 11.6 & 12.0 & 12.4 & 12.4 & 12.0 \\
\hline Other current revenues & 4.3 & 4.1 & 4.4 & 4.3 & 4.3 & 4.1 & 3.9 \\
\hline Capital revenue & 1.4 & 1.7 & 1.7 & 1.8 & 1.4 & 1.4 & 1.4 \\
\hline Total expenditures & 43.4 & 44.4 & 44.7 & 45.8 & 46.3 & 47.8 & 46.2 \\
\hline Primary current expenditure & 35.2 & 36.0 & 37.1 & 38.8 & 39.2 & 40.6 & 39.3 \\
\hline Interest payments & 3.0 & 3.0 & 2.9 & 2.7 & 2.6 & 2.7 & 2.9 \\
\hline Capital expenditures & 5.2 & 5.4 & 4.7 & 4.3 & 4.5 & 4.5 & 4.0 \\
\hline Overall balance 2/ 3/ & -3.2 & -4.3 & -4.2 & -5.3 & -5.3 & -6.0 & -4.6 \\
\hline Including one-off measures & -2.9 & -4.3 & -2.9 & -2.9 & -3.2 & -6.0 & -4.6 \\
\hline \multicolumn{8}{|l|}{ Memorandum items: } \\
\hline Structural balance 4/ & -4.2 & -5.4 & -5.2 & -5.1 & -5.1 & -5.4 & -3.8 \\
\hline Primary balance & -0.2 & -1.3 & -1.3 & -2.5 & -2.7 & -3.3 & -1.7 \\
\hline Primary structural balance 4/ & -1.3 & -2.4 & -2.3 & -2.4 & -2.4 & -2.7 & -1.0 \\
\hline Public debt (Maastricht definition) & 50.5 & 52.9 & 55.5 & 57.0 & 58.6 & 64.0 & 67.6 \\
\hline Nominal GDP (in millions of euros) & 122,270 & 129,308 & 135,434 & 137,523 & 143,029 & 147,395 & 152,844 \\
\hline Change in nominal GDP (in percen & 7.1 & 5.8 & 4.7 & 1.5 & 4.0 & 3.1 & 3.7 \\
\hline Real GDP growth (in percent) & 3.9 & 2.0 & 0.8 & -1.1 & 1.2 & 0.4 & 1.1 \\
\hline
\end{tabular}

Sources: Ministry of Finance; and Fund staff estimates.

1/ Budget figures. Staff projects total revenues and expenditures each about 1 percent of GDP higher.

2/ Excludes one-off measures. Ratios based on GDP series with 2000 as base year.

3 / One-off measures consist of the transfer of the postal pension fund in 2003 , the state enterprises pension funds in 2004, securitization and asset sales.

4/ Structural balances are calculated using the staff's estimates of potential output. Asset sales, including UMTS receipts, the transfer of pension funds and securitization are netted out for purposes of calculating structural balances. 


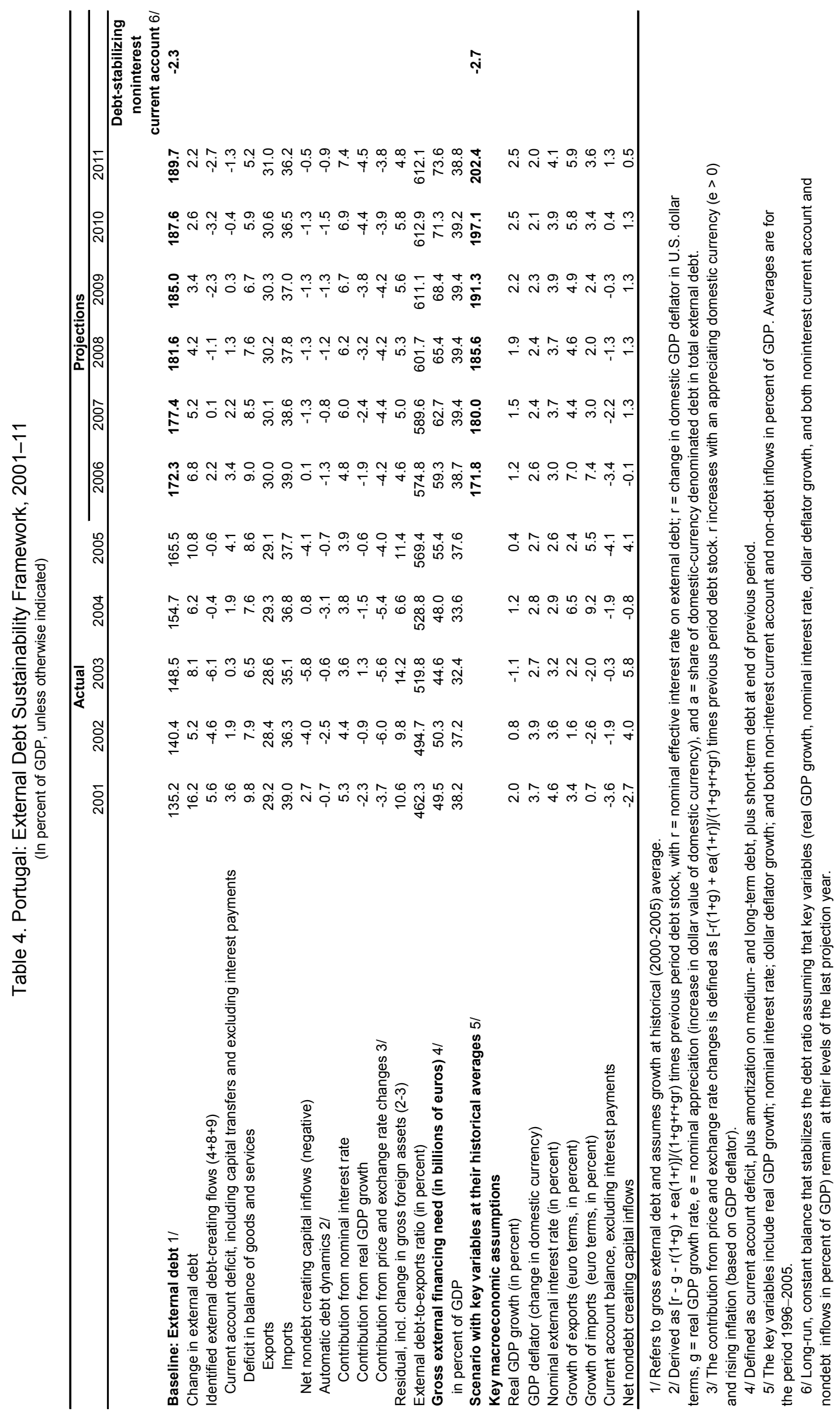




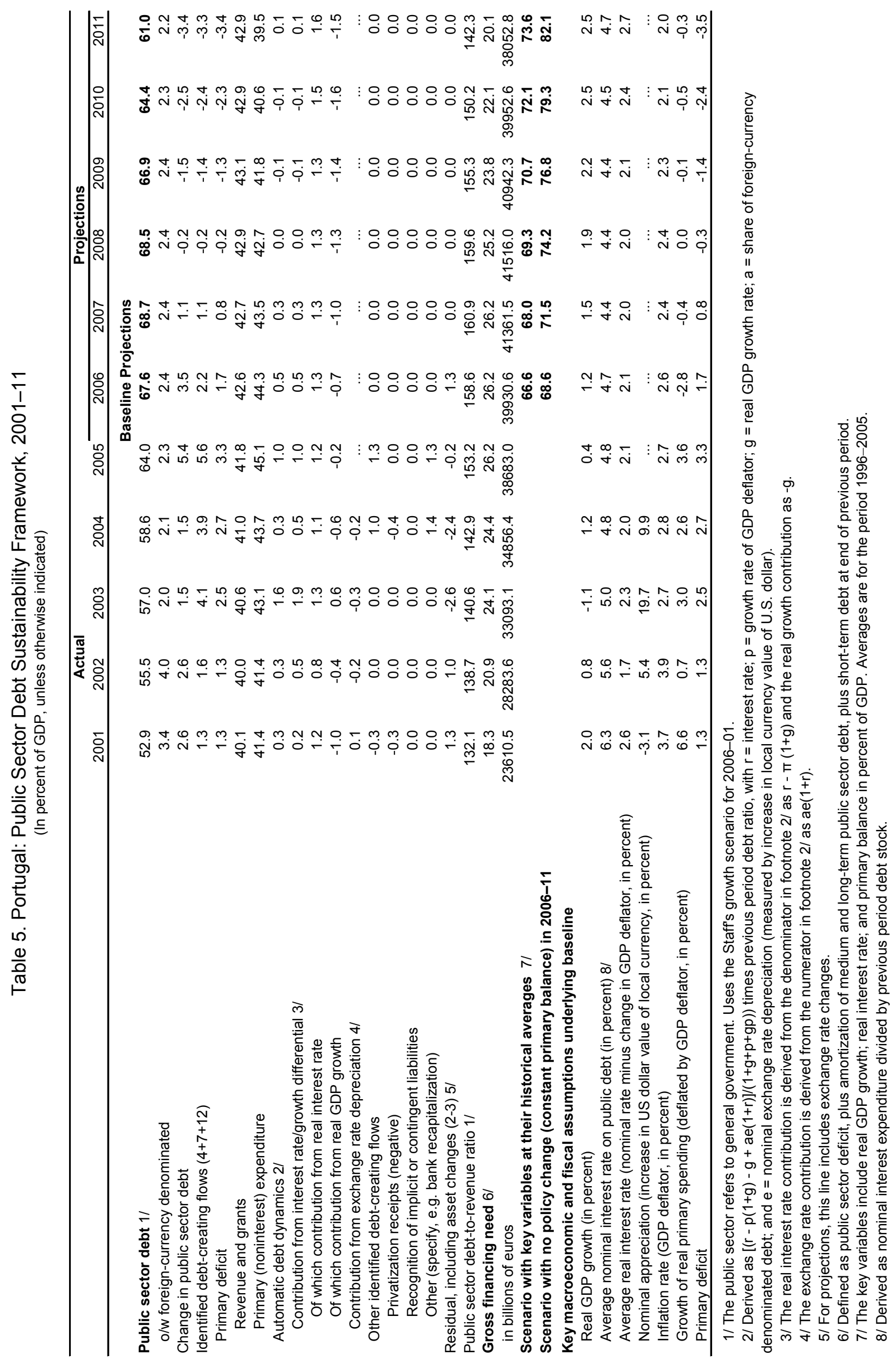


Table 6. Portugal: Indicators of External and Financial Vulnerability, 2001-06

(In percent of GDP, unless otherwise indicated)

\begin{tabular}{|c|c|c|c|c|c|c|c|}
\hline & \multirow[t]{2}{*}{2001} & \multirow[t]{2}{*}{2002} & \multirow[t]{2}{*}{2003} & \multirow[t]{2}{*}{2004} & \multirow[t]{2}{*}{2005} & \multicolumn{2}{|r|}{2006} \\
\hline & & & & & & Latest & Date \\
\hline \multicolumn{8}{|l|}{ External indicators } \\
\hline Exports (goods, annual percent change in euro) & 2.1 & 0.8 & 3.0 & 5.3 & 2.6 & 10.9 & $\mathrm{H} 1$ \\
\hline Terms of trade (goods and services, annual percent change) & 0.5 & 1.6 & 0.3 & -0.8 & -1.5 & $\ldots$ & \\
\hline Current account balance & -9.8 & -7.8 & -5.9 & -7.3 & -9.3 & -10.1 & Q1 \\
\hline Current account balance (including capital transfers) & -8.9 & -6.4 & -4.0 & -5.7 & -8.1 & -8.9 & Q1 \\
\hline Of which: Inward portfolio investment (debt securities, etc.) & 9.2 & 7.9 & 10.1 & 8.1 & 9.4 & -4.6 & Q1 \\
\hline Inward foreign direct investment & 5.4 & 1.4 & 5.5 & 1.3 & 1.7 & 1.8 & Q1 \\
\hline Other investment liabilities (net) & 6.6 & 2.7 & 3.6 & 8.0 & 7.9 & 23.7 & Q1 \\
\hline Central Bank foreign liabilities (in billions of euro) $1 /$ & 8.3 & 8.7 & 2.7 & 8.6 & 12.8 & 13.8 & July \\
\hline Foreign assets of the financial sector (in billions of euro) 2/ & 60.3 & 59.0 & 69.6 & 73.9 & 80.4 & 83.1 & June \\
\hline Foreign liabilities of the financial sector (in billions of euro) 2/ & 95.7 & 102.0 & 116.2 & 118.1 & 128.2 & 141.9 & June \\
\hline Money market rate (real, in percent) & -0.1 & -0.3 & -1.0 & -0.3 & -0.1 & 0.1 & July \\
\hline Stock market index (PSI 20, 1992=3000) & 7,831 & 5,825 & 6,747 & 7,600 & 8,619 & 9,832 & August \\
\hline Share prices of financial institutions $(2005=1000)$ & 977 & 735 & 764 & 856 & 1065 & 1241 & August \\
\hline Spread of 10-year benchmark bond with euro yield (percentage points) & 0.35 & 0.23 & 0.09 & 0.08 & 0.06 & 0.11 & July \\
\hline \multicolumn{8}{|l|}{ Financial sector risk indicators } \\
\hline Foreign exchange assets (in billions of euro) 3/ & 7.0 & 5.9 & 4.9 & 4.6 & 4.8 & 5.2 & June \\
\hline Deposits in foreign exchange (in billions of euro) 4 / & 5.5 & 3.7 & 4.9 & 5.4 & 5.1 & 6.7 & June \\
\hline Share of foreign deposits in total deposits (percent) 4/ & 4.1 & 2.8 & 3.5 & 3.7 & 3.1 & 4.1 & June \\
\hline Share of real estate sector in private credit $5 /$ & 43.7 & 45.6 & 48.2 & 49.5 & 51.3 & 51.4 & June \\
\hline Share of nonperforming loans in total loans $2 / 6$ / & 2.1 & 2.1 & 2.1 & 1.8 & 1.7 & 1.7 & June \\
\hline Risk-based capital asset ratio $7 /$ & 9.5 & 9.8 & 10.0 & 10.4 & $\ldots$ & $\ldots$ & \\
\hline
\end{tabular}

Sources: Bank of Portugal; Ministry of Finance; IMF, Balance of Payments Yearbook database; and Fund staff estimates.

1/ Reserves and foreign liabilities refer to the Bank of Portugal.

2/ Banks only.

3/ Non-euro area currencies assets vis-à-vis the resident and nonresident nonmonetary sector.

4/ Deposits in non-euro area currencies by the resident non-monetary sector and liabilities in non-euro area currencies by the nonresident nonmonetary sector.

5/ Real estate defined as the sum of total credit by monetary financial institutions to individuals for housing and to nonfinancial corporations for construction; private credit defined as total domestic credit excluding the general government. Stocks adjusted for securitization operations.

6/ NPL concern households and nonfinancial corporations.

7/ Capital over risk-weighted assets. Consolidated data for the banking system. 
Table 7. Portugal: Selected Financial Indicators of the Banking System, 2000-05

\begin{tabular}{|c|c|c|c|c|c|c|c|}
\hline & 2000 & 2001 & 2002 & 2003 & 2004 & $20041 /$ & $20051 /$ \\
\hline \multicolumn{8}{|l|}{ Capital Adequacy } \\
\hline Regulatory capital to risk-weighted assets $\left(^{*}\right)$ & 9.2 & 9.5 & 9.8 & 10.0 & 10.4 & 10.2 & 11.3 \\
\hline Regulatory Tier I capital to risk-weighted assets $\left({ }^{*}\right)$ & 7.6 & 7.3 & 7.1 & 7.1 & 7.3 & 7.0 & 7.1 \\
\hline Capital (net worth) to assets $2 /$ & 5.8 & 5.5 & 5.6 & 5.8 & 6.2 & 5.8 & 5.1 \\
\hline \multicolumn{8}{|l|}{ Asset composition and quality } \\
\hline \multicolumn{8}{|l|}{ Sectoral distribution of loans to total loans $\left({ }^{*}\right)$} \\
\hline Households & 48.2 & 47.7 & 48.4 & 48.3 & 49.3 & 49.3 & 50.7 \\
\hline of which: Housing & 36.3 & 36.8 & 38.4 & 38.6 & 39.4 & 39.4 & 41.2 \\
\hline Construction & 8.1 & 8.6 & 8.4 & 8.8 & 8.7 & 8.7 & 8.6 \\
\hline Manufacturing & 8.0 & 7.8 & 7.6 & 7.6 & 6.8 & 6.8 & 6.0 \\
\hline Agriculture & 0.6 & 0.6 & 0.6 & 0.7 & 0.7 & 0.7 & 0.7 \\
\hline Services & 24.8 & 26.7 & 27.5 & 28.7 & 27.9 & 27.9 & 27.5 \\
\hline NPLs to gross loans $\left({ }^{*}\right) 3 /$ & 2.2 & 2.2 & 2.3 & 2.4 & 2.0 & 1.6 & 1.5 \\
\hline Specific provision to NPLs 3/ & 67.7 & 66.8 & 62.8 & 73.0 & 83.4 & 68.0 & 75.0 \\
\hline NPLs net of provisions to capital $\left(^{*}\right) 3 /$ & 8.8 & 9.8 & 12.4 & 9.5 & 4.6 & 7.7 & 7.0 \\
\hline Large exposure to capital $\left(^{*}\right) 3 /$ & $\ldots$ & $\ldots$ & 119.9 & 94.1 & 91.4 & 97.5 & 75.5 \\
\hline \multicolumn{8}{|l|}{ Earnings and Profitability } \\
\hline $\operatorname{ROA}\left({ }^{*}\right)$ & 0.9 & 0.9 & 0.7 & 0.8 & 0.8 & 0.6 & 0.9 \\
\hline $\operatorname{ROE}\left(^{*}\right)$ & 15.1 & 14.9 & 11.7 & 13.9 & 12.8 & 10.8 & 14.6 \\
\hline Interest margin to gross income $\left(^{*}\right)$ & 62.9 & 65.8 & 65.0 & 60.0 & 58.1 & 57.5 & 53.9 \\
\hline Noninterest expenses to gross income $\left({ }^{*}\right)$ & 51.1 & 50.7 & 51.8 & 50.5 & 50.5 & 72.9 & 61.0 \\
\hline Personnel expenses to noninterest expenses & 61.8 & 59.5 & 59.3 & 59.3 & 58.6 & 56.5 & 54.2 \\
\hline Trading and fee income to total income & 29.5 & 25.5 & 26.1 & 27.7 & 29.1 & 33.0 & 39.7 \\
\hline Spread between reference loan and deposit rates 4/ & 4.1 & 4.3 & 3.6 & 3.4 & 3.1 & 3.1 & 3.1 \\
\hline Stock price index of bank shares $5 /$ & 100.0 & 81.2 & 67.6 & 60.6 & 68.3 & 68.3 & 83.2 \\
\hline \multicolumn{8}{|l|}{ Liquidity } \\
\hline Liquid assets to total assets $\left({ }^{*}\right) 6 /$ & $\ldots$ & 15.3 & 12.5 & 17.1 & 15.4 & 15.3 & 15.3 \\
\hline Liquid assets to total short-term liabilities $\left(^{*}\right) 6 /$ & $\ldots$ & 89.0 & 85.6 & 108.6 & 115.2 & 109.1 & 99.0 \\
\hline Loans as percent of deposits $\left(^{*}\right)$ & 114.3 & 121.0 & 127.7 & 126.9 & 126.2 & 136.5 & 143.5 \\
\hline FX liabilities to total liabilities $7 /$ & 10.7 & 9.9 & 9.0 & 9.0 & 7.9 & 7.9 & 8.3 \\
\hline \multicolumn{8}{|l|}{ Sensitivity to market risk } \\
\hline Net open position in FX to capital $\left(^{*}\right)$ & $\ldots$ & $\ldots$ & 7.1 & 4.7 & 3.9 & 4.0 & 4.5 \\
\hline Net open position in equities to capital & $\ldots$ & $\ldots$ & 1.8 & 0.2 & 1.8 & 1.8 & 1.3 \\
\hline
\end{tabular}

Sources: Bank of Portugal; and Fund staff estimates.

$\left({ }^{*}\right)$ Core Financial Sector Indicators.

1/ For 2005 the figures are for the sample of institutions that are already complying with IAS, accounting as of December 2004 for about 87 per cent of the usual aggregate considered. To ensure comparability, the figures for 2004 for this sub-sample are also presented.

2/ On accounting basis; consolidated.

3/ On a consolidated basis. NPLs are defined as credit to customer overdue. For comparable 2004 and 2005 figures: The concept of NPL is only applicable at an individual level and for prudential purposes. The following definition of NPL's will be used: principal and interest past due for more than 90 days (amount overdue only) + future instalments of loans fallen due and classified as doubtful, according to criteria that include initial maturity, the time elapsed since the first instalment fallen due, and the relative importance of fallen due instalments in each loan.

4/ Based on weighted averages of lending rates to households and to nonfinancial corporations and of deposit interest rates for the two sectors.

5/ PSI Financial Services (Euronext Lisbon); 01/01/2000 =100.

6/ Three-month residual maturity horizon.

7/ FX liabilities include foreign currency deposits and deposit-like instruments of resident nonmonetary sector and claims of non-resident vis-à-vis resident monetary financial institutions (excluding Bank of Portugal). 


\section{Appendix I. Portugal: Fund Relations}

(As of July 31, 2006)

I. Membership Status: Joined March 29, 1961. Portugal accepted the obligations of Article VIII, Sections 2, 3, and 4 of the Fund's Articles of Agreement effective September 12, 1988.

II. General Resources Account:

Quota

$\begin{array}{cc}\text { SDR Million } & \text { Percent Quota } \\ 867.40 & 100.00 \\ 749.87 & 86.45 \\ 117.56 & 13.55 \\ & \\ \text { SDR Million } & \text { Percent Allocation } \\ 53.32 & 100.00 \\ 73.63 & 138.08\end{array}$

IV. Outstanding Purchases and Loans: None

V. Latest Financial Arrangements:

\begin{tabular}{rrrrr}
\hline Type & $\begin{array}{r}\text { Approval } \\
\text { Date }\end{array}$ & $\begin{array}{r}\text { Expiration } \\
\text { Date }\end{array}$ & $\begin{array}{r}\text { Amt Approved } \\
\text { (SDR Million) }\end{array}$ & $\begin{array}{r}\text { Amt Drawn } \\
\text { (SDR Million) }\end{array}$ \\
\hline Stand-by & Oct. 7, 1983 & Feb. 28, 1985 & 445.00 & 259.30 \\
\hline
\end{tabular}

VI. Projected Payments to Fund: None

VII. Exchange Rate Arrangements:

Portugal entered the final stage of European Economic and Monetary Union on January 1, 1999 , at a rate of 200.482 Portuguese escudos per 1 euro. The official currency was changed to the euro on January 1, 2002.

Portugal maintains an exchange system free of restrictions on the making of payments and transfers for current international transactions, except for exchange restrictions maintained solely for the preservation of national or international security; those restrictions have been notified to the Fund in accordance with Executive Board Decision No. 144-(52/51).

VIII. Article IV Consultation: Portugal is on a standard 12-month consultation cycle. The last Article IV consultation discussions were concluded on October 14, 2005.

IX. Technical Assistance:

$\begin{array}{llll}\text { Year } & \text { Dept. } & \text { Purpose } & \text { Date } \\ 1998 & \text { STA } & \text { Finalize Metadata for DSBB } & 9 / 98 \\ 1998 & \text { STA } & \text { Revision of Monetary Statistics } & 11 / 98\end{array}$

X. ROSCs:

Standard Code Assessment Fiscal Transparency
Date of Issuance

December 1, 2003

\section{Country Report No.}

03/373

XI. Resident Representative: None 


\section{Appendix II. Portugal: Statistical Issues}

1. Data provision to the Fund is adequate for surveillance purposes. Notwithstanding some recent improvements, statistical weaknesses continue to hamper the assessment of economic developments. Portugal subscribes to the Special Data Dissemination Standard (SDDS), and the relevant metadata have been posted on the Dissemination Standards Bulletin Board. Portugal has taken a flexibility option regarding the timeliness in the reporting of wages. Portugal's publication policy is characterized by a high degree of openness and with extensive use of the Internet. The Bank of Portugal, Ministry of Finance, and National Statistics Office (INE) have several websites with long- and short-term economic indicators and data.

2. Real sector statistics were improved in the fall of 2000, when INE published a full set of national accounts based on ESA95 methodology, including quarterly GDP estimates. The authorities are in the process of rebasing national account statistics to 2000. As statistical weaknesses remain, the Bank of Portugal continues to produce separate estimates of the annual national accounts. Shortcomings in timely and high quality monthly and quarterly data on output, employment, and total wage compensation hamper the monitoring of within-year developments in the labor market. Unemployment data also suffer from statistical problems caused, inter alia, by frequent revisions to the measurement of unemployment and sampling rotations.

3. Fiscal sector data have undergone a number of revisions during the transition to ESA95, sizably altering revenue and expenditure and hampering comparisons across years. The 2001-04 budgets have been presented in a manner consistent with recent changes in national and fiscal accounting methodology. Intra-year budget data is available only on a cash basis. In 2002 INE started to publish data for the Social Security Fund on a monthly basis with a 45 days delay, and in 2003 for the Autonomous Funds on a quarterly basis with a 75 days delay. Except for the local and general government, data broadly meet the SDDS timeliness standards. A project is underway concerning quarterly general government statistics on an accrual basis, but there is no timetable for publication.

4. Trade and balance of payments data are provided according to the IMF's fifth edition of the Balance of Payments Manual. Although the external trade data meet the timeliness standards, frequent and sizeable revisions hamper their usefulness. The portfolio investment collection system has a simplified threshold (all reporting institutions whose monthly transactions do not reach $€ 500$ million and, at the same time, have less than $€ 500$ million in outstanding amounts may report only once a year, using a simplified form). The authorities estimate however, that only a very small portion of transactions (in 2005, less than 1 percent) are not captured on a monthly basis by this threshold, and that this reporting simplification does not significantly hamper the quality of the monthly balance of payments. Moreover, they believe that all transactions below this threshold are included in the first release of the annual balance of payments data, and the monthly numbers are revised accordingly. 


\section{Portugal: Table of Common Indicators Required for Surveillance}

(As of September 19, 2006)

\begin{tabular}{|c|c|c|c|c|c|}
\hline & $\begin{array}{l}\text { Date of } \\
\text { Latest } \\
\text { Observation }\end{array}$ & $\begin{array}{c}\text { Date } \\
\text { Received }\end{array}$ & $\begin{array}{l}\text { Frequency } \\
\text { of Data }^{7}\end{array}$ & $\begin{array}{l}\text { Frequency } \\
\text { of } \\
\text { Reporting }^{7}\end{array}$ & $\begin{array}{l}\text { Frequency } \\
\text { of } \\
\text { Publication }\end{array}$ \\
\hline Exchange Rates & 09/19/06 & 09/19/06 & $\mathrm{D}$ & $\mathrm{D}$ & $\mathrm{D}$ \\
\hline $\begin{array}{l}\text { International Reserve Assets and Reserve } \\
\text { Liabilities of the Monetary Authorities }{ }^{1}\end{array}$ & 07/06 & $08 / 06$ & M & M & M \\
\hline Reserve/Base Money & $08 / 06$ & $08 / 06$ & M & M & M \\
\hline Broad Money & 08/06 & $08 / 06$ & M & M & M \\
\hline Central Bank Balance Sheet & $07 / 06$ & 08/28/06 & M & M & M \\
\hline $\begin{array}{l}\text { Consolidated Balance Sheet of the Banking } \\
\text { System }\end{array}$ & 07/06 & $08 / 28 / 06$ & M & M & M \\
\hline Interest Rates ${ }^{2}$ & $09 / 06$ & 09/01/06 & W & W & W \\
\hline Consumer Price Index & $08 / 06$ & 09/06 & M & M & M \\
\hline $\begin{array}{l}\text { Revenue, Expenditure, Balance and } \\
\text { Composition of Financing }{ }^{3}-\text { General } \\
\text { Government }{ }^{4}\end{array}$ & $07 / 06$ & $08 / 06$ & M & M & M \\
\hline $\begin{array}{l}\text { Revenue, Expenditure, Balance and } \\
\text { Composition of Financing }{ }^{3}-\text { Central } \\
\text { Government }\end{array}$ & $07 / 06$ & $08 / 06$ & M & M & M \\
\hline $\begin{array}{l}\text { Stocks of Central Government and Central } \\
\text { Government-Guaranteed Debt }{ }^{5}\end{array}$ & $06 / 06$ & 09/06 & M & M & M \\
\hline External Current Account Balance & 2006 Q2 & $08 / 06$ & Q & Q & Q \\
\hline Exports and Imports of Goods and Services & 2006 Q2 & $08 / 06$ & Q & Q & Q \\
\hline GDP/GNP & 2006 Q2 & $08 / 06$ & Q & Q & Q \\
\hline Gross External Debt $^{6}$ & 2006 Q1 & $06 / 06$ & $Q$ & Q & Q \\
\hline
\end{tabular}

${ }^{1}$ Includes reserve assets pledged or otherwise encumbered as well as net derivative positions.

${ }^{2}$ Both market-based and officially determined, including discount rates, money market rates, rates on treasury bills, notes and bonds.

${ }^{3}$ Foreign, domestic bank, and domestic nonbank financing.

${ }^{4}$ The general government consists of the central government (budgetary funds, extra budgetary funds, and social security funds) and state and local governments.

${ }^{5}$ Including currency and maturity composition.

${ }^{6}$ Daily (D), weekly (W), monthly (M), quarterly (Q), annually (A), irregular (I); and not available (NA). 


\section{Statement by the IMF Staff Representative October 18, 2006}

1. This statement provides information that has become available since the issuance of the Staff Report for the 2006 Article IV Consultation. The new information does not change the thrust of the staff appraisal.

\section{Short-term indicators are mainly positive, further supporting the assessment} that a gradual recovery is underway. Export volumes rose strongly in July and industrial production grew solidly in August, as did the Bank of Portugal's coincident indicator of economic activity. Considered alongside recent developments with oil prices, these indicators imply that the risks related to the staff's growth forecasts for 2006-07 are tilted to the upside. Data on budget execution through September suggest that fiscal performance remains on track, although the government will of course need to continue monitoring developments closely.

3. Further progress has been made with structural reform. The authorities have signed an agreement with social partners regarding the pension reform and now expect to submit the reform to Parliament next month, behind the schedule indicated in the Staff Report but still in time for its effects to be incorporated in the 2007 budget. In addition, the government has submitted to Parliament new laws on local government financing consistent with the plans outlined in the Staff Report. It expects to submit new laws on the financing of regional governments to Parliament next month, with approval anticipated by January 2007.

\section{The 2007 budget proposal submitted to Parliament on October 16 targets a} deficit of 3.7 percent of GDP, in line with EDP commitments. While the staff has not had an opportunity to discuss the budget proposal with the authorities, our preliminary analysis suggests that all of the planned deficit reduction of 0.9 percent of GDP is to come from the expenditure side, consistent with the government's medium-term strategy. About threequarters of the targeted savings would arise from reductions in the public wage bill, reflecting wage moderation, the renewed suspension of the system of automatic promotions, and staff attrition, owing in part to the impact of the public sector reorganization and civil service reforms. The budget also targets cuts in investment. Continued careful monitoring of expenditure, as well as vigorous implementation of planned reforms, will be necessary to achieve the deficit target. This is especially true as the real GDP growth forecast underlying the budget -1.8 percent next year-is somewhat more optimistic than the staff's current baseline forecast of 1.5 percent. 


\section{Statement by Arrigo Sadun, Executive Director for Portugal and Luis Saramago, Assistant to Executive Director October 18, 2006}

We start by thanking both the Article IV and the FSAP staff teams for their candid and constructive approach to these consultations. The Article IV report is broadly in line with the authorities' own views and mostly supportive of their policy choices. The FSSA in turn provides wide-ranging insights that essentially confirm the financial system as a solid pillar of the Portuguese economy. Staff's recommendations are welcome and will be taken into due consideration. As for the Selected Issues Paper, although it addresses relevant matters, we must nonetheless point out that major caveats preclude firm conclusions (see page 8 below).

\section{Key Points}

- After several years of sluggish growth, the Portuguese economy is now recovering at a still modest but nevertheless faster-than-anticipated pace, driven by strong external demand. Inflation remains subdued and unemployment started to decline.

- That tentative recovery should be seen against the background of an ongoing and long run shift in the economy's specialization pattern, towards higher value-added activities, in turn supported by significant corporate restructuring and structural reforms.

- The fiscal deficit target agreed under the SGP for 2006 (a cut amounting to 1.4 percent of GDP) is well within reach. This will mostly result from the lagged effect of the 2005 VAT rate rise, sustained progress against tax evasion and expenditure restraint.

- The financial system is "sound, well managed and competitive", according to the FSSA. Thorough stress tests further indicate its ability to safely withstand even severe shocks. Supervision of financial institutions and of the settlement and payments systems was found to "compare very well with international standards".

- In office since March 2005 and facing elections only in 2009, the single-party majority government is strongly committed to fiscal consolidation without one-off measures and to competitiveness-enhancing structural reforms. Implementation on both counts is proceeding well and opinion polls consistently show robust public support.

\section{Recent Developments}

Economic activity in Portugal has been accelerating since late last year. The initial projection of a 0.8 percent GDP growth rate in 2006 (against 0.3 percent in 2005) was already updated to 1.2 percent and may yet be revised upwards again. Indeed, the most recent figures 
available for leading indicators and from confidence surveys of different economic agents generally confirm that favorable trend.

The main driving force behind this recovery has been net external demand (a 2.6 p. p. contribution to year-on-year GDP growth of 0.9 percent in the second quarter of 2006). Nominal exports of goods increased by 11.1 percent, year-on-year, in the first seven months of 2006 (30.1 percent to non-EU destinations), outpacing the 7.1 percent increase in imports (a decrease of 1.0 percent excluding fuel).

The recovery has already proved strong enough to support a decrease of the unemployment rate, from 8.0 percent in the final quarter of 2005 to 7.3 percent in the second quarter of 2006. As for inflation, the year-on-year HICP rate of change fell to 2.0 percent in August (1.0 percent in core CPI terms), thus standing below the euro area average for the second month in a row, as the effect of the July 2005 VAT rate increase wears off.

\section{Macroeconomic Overview}

The Portuguese economy has endured a period of low growth, rising unemployment and increasing external imbalances since the beginning of the current decade. That was largely the result of a few sizeable exogenous shocks, on top of two major endogenous trends. First of the latter is slower-growing private consumption and investment, as agents adapted to rising indebtedness from the mid-nineties onwards - in turn resulting from the sharp decline of interest rates in the context of first-wave EMU accession (see page 7, third bullet below).

Second, increasingly apparent fiscal imbalances, which weighed on confidence until a credible consolidation strategy was adopted in 2005 - and require adjustments that put a toll on internal demand. As for the exogenous shocks, they included the euro area slowdown after 2000 (destination of about 2/3 of Portuguese exports), the increase in oil prices after 2003 (Portugal is relatively more oil-dependent than other EU-15 countries) and enhanced external competition (from both Central-Eastern European and Asian countries).

Against this difficult background, which can be further aggravated by taking into account a few other impending risks (such as the perennial prospects of tighter monetary conditions and possible unfavorable developments in global financial markets), some important mitigating factors should nevertheless be emphasized:

- First, the fact that a credible strategy (so perceived by public opinion and the markets, according to available indicators) has indeed been put forward by the new government, not only as regards sustained fiscal consolidation but also competitiveness-enhancing structural reforms, at several levels (see below). 
- Second, and so far only partially reflected in economic data, an increasingly apparent reaction to the changing environment from the private sector itself. This may arguably amount to a long term shift in the economy's specialization pattern and can be detected in a few indicators. One is the decreasing share of lower-technology products in total exports (from 45 percent in 2001 to 36 percent in the first half of 2006); another is the evidence of significant corporate restructuring in recent years, perceivable at the sector and firm level; yet another, the expected recovery of FDI, concentrated in higher-value added activities (which should be seen against the fact that Portuguese subsidiaries of several major international corporations are among their most efficient worldwide).

- Third, the need to take into account the important contribution to macroeconomic stability and growth prospects that results from having a solid and competitive financial system - a point to be considered together with the need to put into perspective the significance of current debt levels (see page 7 below).

\section{Fiscal Policy}

An unsustainable expansion of current primary expenditures, coming from the past decade, led to the emergence of a sizeable budget deficit in 2001, as the economy slowed down and the EMU-induced effect of falling interest payments wore off. Over the three following years, one-off measures allowed for the deficit to be kept within SGP-agreed limits, but the underlying problems were not appropriately tackled. After the current single-party majority government took office in March 2005, an independent commission was appointed (headed by the Governor of the Bank of Portugal) to assess the true condition of public finances. It concluded that the original 2005 budget had significant shortcomings and would result, without policy changes, in an overall deficit amounting to 6.5 percent of GDP.

Against this background, the new government stated its determination to address the structural causes of fiscal imbalances, thus pledging to abstain from one-off measures and to focus on expenditure reforms. A supplementary budget was approved in July 2005, within the context of a strategy to take the deficit below 3 percent of GDP by 2008 - and further down beyond that year, to long-term sustainable levels. This strategy, supported by the EU's Ecofin Council, encompassed an initially larger emphasis on revenue measures most notably increases of VAT as well as fuel and tobacco tax rates. The reason was that, although several measures on the expenditure side immediately started to be prepared, and many of them were quickly implemented, the kind of structural expenditure reforms envisaged would necessarily take some time to bear significant fruits.

Actions taken on the expenditure side in 2005 and 2006 included a vast array of specific measures - such as, for instance, a freezing of public servants' career progression, a streamlining of the school network (involving the closure of about 1500 primary schools with a small number of students, to be redeployed), the ongoing corporatization of public hospitals 
and a multi-year agreement with the pharmaceutical industry to supply the National Health System (NHS), among many others. The three latter measures are part of a wide-ranging effort to improve the quality and cost-effectiveness of public services, especially in the critical areas of healthcare, education, justice and local administration.

Beyond such specific measures, other important initiatives include the advancement of privatizations (eight companies to be partly or fully divested in 2006/07, with at least 80 percent of the proceedings going for debt reduction) and new laws on the financing of local and regional governments, the former submitted to Parliament just a few days ago and the latter ready for submission in the coming month (with the common feature of setting heavy penalties for breaching indebtedness limits, while increasing responsibility for revenue collection, and therefore accountability for expenditure choices). On top of the above, two major fiscal reforms are being implemented. It is worth noting that both are broadly in line with their planned timeframes - indeed, the authorities believe that a critical requirement for deep reforms of this kind to be successful is their careful preparation, discussion with stakeholders and communication to the public.

Social security. A first stage of reform was implemented in 2005, focusing on civil servants. It resulted in the elimination of several especially favorable pension and healthcare regimes, as well as the convergence of the general civil service pension system to the less generous private sector one. That implied, for instance, a gradual increase of civil servants' retirement age from 60 to 65 years (or more - see below) and of the minimum service period for full-pension benefits from 36 to 40 years. The second stage is the reform of the general social security system itself, which is about to be submitted to Parliament - after an agreement was reached with most social partners just a few days ago - and will become operational at the beginning of 2007, as planned. It involves, most notably, the establishment of a regularly updated link between the retirement age and life expectancy, the anticipation of another reform previously scheduled for 2017 that will consider a worker's entire career as the reference period for pension calculation (instead of the 10 best of the last 15 years, as until now), the strengthening of disincentives to early retirement and the introduction of a pension cap.

Public Administration. Under this broad caption, and in connection with both the civil servants' pension system reform and their career progression freezing, several interlinked building blocks are being developed. One is the reorganization of public services, which already resulted in the approval of a new and carefully crafted macrostructure of 331 services (36 percent less than before), together with an ongoing shake-up of procedures. Another, expected to be in place in 2007, involves the streamlining of careers (including a significant reduction in the number of career paths), together with the introduction of a new merit-based system for the evaluation of civil servants and the adoption of performance targets for public services (linked to budget allocations). Yet another is the introduction of a new mechanism for labor mobility within public administration, which aims to increase 
flexibility and includes the possibility of placing civil servants in a "redundancy pool" with a gradual decrease in wages (eventually falling to $1 / 3$ of the initial base salary). Finally, the reiterated commitment to gradually reduce the number of civil servants, translated into a broad replacement rate of one entrant for every two departed.

Although the authorities' strategy for fiscal consolidation could only start to be effectively implemented after the 2005 supplementary budget was in place, meaning well into the second half of the year, that nevertheless proved sufficient to attain the budgeted deficit target ( 6 percent of GDP, without one-off measures - against the 6.5 percent projected, in the absence of corrective actions, by the above-mentioned independent commission).

The fiscal consolidation strategy calls for a 1.4 p.p. deficit reduction in 2006 (1.7 p.p. in structural terms), which will take the deficit to 4.6 percent of GDP. This goal is well within reach, as can be ascertained from available figures for ongoing budget execution. As regards the State sector, total revenues increased by 7.6 percent in the year up to August over the same period of 2005, while total expenditures increased by 2.8 percent (1.2 percent for current primary expenditures). Half-year figures for autonomous services and funds, as well as for the NHS, are also quite positive - in particular, the increase in expenditures over the same period of 2005 was 0.7 and 1.0 percent, respectively.

The authorities have reiterated their commitment to take additional measures, if needed, in order to ensure a successful accomplishment of the deficit target for 2006 (and likewise beyond that). A final reference should be made to the important contribution to fiscal consolidation that has been coming from the enhanced efficiency of tax administration since 2004.

\section{Other Structural Issues}

The second major economic priority adopted by the newly-elected government in 2005 , besides fiscal consolidation, was the creation of conditions for a sustained recovery of growth and employment, through a durable enhancement of productivity and overall competitiveness. That is being addressed both with a long-term perspective (actions focused on human capital development) and a shorter-term one (actions broadly aimed at fostering business activity). Some of the most significant:

- Technological Plan. Focused on the promotion of technology, innovation and general knowledge, its first phase (2005/06) encompasses 112 specific measures. Executed at more than 80 percent, they include such actions as full-country broadband internet coverage, fiscal incentives for corporate investment in R\&D and the development of a country-wide network of high-tech logistic platforms. 
- Simplex. Closely connected with the previous initiative, it focuses on cutting red tape and generally simplifying public procedures to the benefit of citizens and businesses. With 333 specific measures being implemented in 2006, its most emblematic one is the possibility of starting a business online and in less than one hour (more than 8000 firms thus created so far). This by itself allowed Portugal to climb 5 places in the Doing Business Indicators ranking of the World Bank - several other measures introduced after its cut-off date for data submission will likely allow for further progress next year.

- Education and professional training. A vast set of specific measures aimed at having an effective impact on the ground, such as longer hours of school operation, broadband internet connections in all schools, English classes starting at primary grade and protocols between some of the leading universities worldwide and Portuguese ones, as well as between the latter and business.

- Justice system. Broadly aimed at improving the system's efficiency and swiftness, as well as its credibility, a formal agreement was signed between the majority party and the main opposition one in September 2006 (thus securing a broad consensus in this sensitive area). It comes on top of other specific measures to the same purpose and includes dispositions for such things as adjusting the territorial boundaries of courts (relieving overburdened ones), enhancing legal mediation and introducing several streamlining amendments to the Penal and the Penal Procedure Codes.

- Competition and market flexibility. Enhanced competition in critical markets such as those for energy and telecoms is being implemented through regulatory changes, while the Competition Authority is having an increasingly higher impact on market conditions at various levels. Other initiatives worth mentioning in this context include the advancement of privatizations and a new law for the rental housing market - which will allow for rent levels of older leases (about 60 percent of total residential leases) to be gradually increased - thus eventually ending a long-term bottleneck that significantly affected the real estate sector. As for labor market reforms, the authorities do not see them as a priority at this time. A new Labor Code was introduced about two years ago and its full impact is still being evaluated.

\section{Financial System Stability Assessment}

The Portuguese authorities welcomed this FSAP exercise as a timely opportunity for an independent and in-depth review of the financial system and they further welcomed the productive engagement with the FSAP staff team. They now welcome the FSSA and its supplements, which provide a fairly accurate assessment on the system, appropriately emphasizing its soundness, competitiveness, profitability, resilience to shocks and high quality of management. Moreover, they appreciate the references to the excellence of 
supervision, as regards both financial institutions and the settlement and payments systems, which was found to compare very well with best international standards.

The authorities further appreciate the fact that staff's recommendations - which will be taken into due consideration - mostly refer to actions they are already implementing. Likewise, the authorities welcome staff's indications that identified risks to the financial outlook should continue to be appropriately monitored - they will certainly remain committed to their responsibilities. Finally, a few clarifying points:

- Staff's remarks regarding "exposure to real estate-related activities" (page 15, first bullet) must be taken with a qualification of paramount importance. A clear distinction needs to be made between household mortgages (the largest share) and other real estate-related loans, as the former carry a much lower probability of default - and so help to keep credit risk under control in case of adverse macroeconomic developments. Capital requirements for household mortgages are actually half of those for other real estate-related loans. In addition, there is no indication of an over-inflated housing market (indeed, house prices have been almost flat overall for more than five years, in nominal terms - see figure 4 of the FSSA).

- Likewise, staff's call for caution as regards credit "concentration in a few large corporate borrowers" (page 15, second bullet) must also be qualified. Indeed, the probability of default for large corporate borrowers should be acknowledged as significantly lower than that for smaller ones. Moreover, risk is appropriately diversified among large borrowers - large exposures "are closely supervised and within the prudential limits”, as recognized by staff.

- On an additional note related to the first bullet above, a few considerations are warranted regarding household indebtedness - relevant also in line of the Article IV report (for instance, the bullet on page 12: "necessary adjustments to household balance sheets"). We would argue that there is no evidence of a household balance sheet problem under current circumstances. The drastic reduction of liquidity constraints since the mid-nineties, in the context of first-wave EMU accession, implied a stock adjustment which translated into buoyant household expenditures for a number of years - followed later on by a corresponding deceleration, which still persists. Moreover, as acknowledged in pages 12 and 13 of the FSSA, interest payments remain manageable, in spite of rising household debt (they are stable since 2003 and more than 100 basis points lower than in 2001, as a percentage of disposable income); household wealth "quite comfortably exceeds debt levels", as the former currently amounts to more than 2.5 times the latter (household debt is also topped by net financial wealth on its own); finally, the evolution of housing prices in recent years suggests that no speculative pressures are present in this market (see the second bullet above). 


\section{Selected Issues Paper}

The authorities acknowledge that both chapters of this paper address relevant issues competitiveness and corporate investment. They can further agree that the paper conveys, to some extent, worthy messages. Nevertheless, they must emphasize that well-known major caveats do not allow for firm conclusions to be taken from the analysis - much the less clear-cut policy recommendations.

The chapter on competitiveness is fraught with difficulties, given the shortcomings of available methodologies. For instance, the endogenous behavior of the real exchange rate, related to the economic growth process, is usually disregarded by the type of analysis followed. Moreover, traditional price competitiveness indicators are well known for their inability to incorporate structural changes associated with different product specialization across countries and with increasing competition from such countries as emerging market ones. Profit Margin Indicators, especially when computed in levels or compared across countries, rely on several structural parameters which may lead to particularly misleading results. The traditional decomposition used within the Constant Market Share analysis also presents several limitations that have been extensively discussed in the literature.

The bottom line is that we should be extremely careful about taking conclusions in this context, especially as regards estimates of a gap between the observed and the equilibrium exchange rate or the duration of competitiveness adjustments. The key point acknowledged by staff in the chapter's Concluding Remarks - "these calculations are simply illustrative and are subject to considerable uncertainty" (page 16 of the SIP) should therefore be strongly emphasized.

As for the chapter on corporate investment, the empirical investigation seems to suffer from significant shortcomings that undermine its conclusions. In particular, the debt overhang hypothesis as an important reason for the unfavorable performance of corporate investment in Portugal is not supported by available indicators. Indeed, the adjustment of a debt overhang episode is usually characterized by a slowdown, or even a decline, in corporate investment (as recorded in Portugal since 2001). However, for the debt overhang hypothesis to hold, data on profitability and financing conditions must also reflect this situation - which usually means a high debt service level, a high number of default situations and a decline in corporate credit. All of the latter are at odds with available indicators for Portugal. 
Public Information Notice (PIN) No. 06/124

FOR IMMEDIATE RELEASE

October 24, 2006
International Monetary Fund

$70019^{\text {th }}$ Street, NW

Washington, D. C. 20431 USA

\section{IMF Executive Board Concludes 2006 Article IV Consultation with Portugal}

On October 18, 2006, the Executive Board of the International Monetary Fund (IMF) concluded the Article IV consultation with Portugal. ${ }^{1}$

\section{Background}

A gradual economic recovery is underway after a largely flat outturn in 2005. Year-on-year GDP growth accelerated to 1 percent in the first half of 2006, on the strength of a pickup in exports and resilient private consumption, though investment remained weak. Meanwhile, the unemployment rate reached a seven-year high of 8 percent in the last quarter of 2005, before moderating to 7.3 percent in the second quarter of 2006. Due in part to an increase in the rate of the ValueAdded Tax in mid-2005, inflation rose to 2.7 percent in the first half of 2006 . The current account deficit (including capital transfers) widened to 8.1 percent of GDP last year.

High private indebtedness (especially among households), weak competitiveness, and significant fiscal consolidation are expected to weigh on growth in the near future, but stronger foreign demand is forecast to lead to a better external contribution to growth than in previous years. Real GDP is projected to grow by about 1.2 percent in 2006 and 11/2 percent in 2007.

The authorities have committed to reduce the fiscal deficit from 6 percent of GDP in 2005 to below 3 percent of GDP by 2008 without recourse to one-off measures. The 2006 budget targets a reduction in the deficit to 4.6 percent of GDP. A little more than half of this year's deficit reduction is to come from the full-year impact of revenue measures announced last year, with the balance coming mostly from savings in the public wage bill and intermediate consumption. Several major structural fiscal reforms are expected to contribute to achieving the medium-term deficit targets,

\footnotetext{
${ }^{1}$ Under Article IV of the IMF's Articles of Agreement, the IMF holds bilateral discussions with members, usually every year. A staff team visits the country, collects economic and financial information, and discusses with officials the country's economic developments and policies. On return to headquarters, the staff prepares a report, which forms the basis for discussion by the Executive Board. At the conclusion of the discussion, the Managing Director, as Chairman of the Board, summarizes the views of Executive Directors, and this summary is transmitted to the country's authorities.
} 
including measures to streamline the public sector, flexibilize the civil service, and overhaul the social security system for private sector workers. Steps are also underway to improve the efficiency of spending on health and education, and to modify the system of local government financing.

A Financial Sector Assessment Program mission undertook an extensive review of Portugal's financial system, finding it to be generally sound. The banking sector has proven resilient to the economic downturn: indicators point to improved capitalization, solid profitability and low nonperforming loans. Strong growth of bank lending to households, especially for mortgages, has led to a continued increase in the private sector credit-to-GDP ratio, which reached about 150 percent by the end of 2005 (the highest value in the EU). Bank lending remains concentrated among a limited number of large corporates (albeit within supervisory limits), and the exposure of banks' employee pension schemes to the stock market is relatively high. However, the FSAP mission considered these risks to be manageable.

\section{Executive Board Assessment}

While welcoming the modest recovery of output growth and recent progress on economic reforms, Executive Directors concurred that Portugal continues to confront considerable challenges to accelerate growth and resolve large fiscal and external imbalances. Directors encouraged the authorities to use the opportunity provided by the current favorable environment to address these challenges through a coordinated approach, noting that decisive progress in each area could generate a virtuous cycle of faster growth and adjustment in the medium term.

Directors considered the government's strategy to be broadly appropriate, but underscored that firm and sustained implementation remains essential to its success. They supported the focus on expenditure-based fiscal consolidation to bring the deficit under 3 percent of GDP by 2008 without one-off measures; on structural fiscal reforms to contain aging-related spending, raise the efficiency and quality of public spending, and promote the sustainability of the public finances; and on reforms to enhance competition in product markets and improve the business environment, so as to spur productivity growth.

Directors concurred that achievement of the 2006 fiscal deficit target of 4.6 percent of GDP would be important to ensuring the credibility of the adjustment effort, and welcomed the authorities' commitment to reinforce budget measures, if necessary, to achieve the deficit target. Going forward, they stressed the importance of shifting the fiscal effort from reliance on revenue measures toward the spending side in order to address the root cause of current fiscal weaknesses, namely, the steady rise of spending-especially on pensions and wages-over the last decade. This will require moving forward with planned reforms to the civil service, to the structure of the public sector, and to the social security system for private sector workers. Directors urged the authorities to work toward decisive implementation of these structural fiscal measures. They also supported ongoing efforts to improve arrangements for local and regional government financing, and the authorities' consideration of a multiyear budget framework with explicit expenditure ceilings.

Directors recognized that additional fiscal adjustment would be needed beyond 2008 to ensure long-term sustainability and to create scope for automatic fiscal stabilizers to operate in future downturns. Forecasts of aging-related spending point to large increases in pension and health expenditure in the coming years, and a sustained effort will therefore be needed to prevent the 
public debt from rising sharply over the long term. It would be important to reevaluate the adequacy of any medium- to long-term fiscal target periodically in light of developments with output growth and health and pension spending.

Directors stressed the need for progress with structural reforms aimed at supporting the continued transformation of the Portuguese economy and its public sector, by strengthening domestic competition, improving the business environment, and increasing government efficiency. They welcomed the Government's Technological Plan and recent steps to remove bureaucratic and regulatory impediments to business, as well as the authorities' intention to accelerate legal processes and ease licensing burdens for firms. Directors saw the reinvigorated privatization process as a key component of the overall strategy to reduce the role of the state in the economy and enhance efficiency. They also supported the work of the Competition Authority, and called for continued efforts to enhance competition, especially in key network sectors. Efforts to upgrade the educational system should also remain a priority.

While welcoming recent changes to the unemployment compensation system, Directors encouraged the authorities to pursue more fundamental labor market reform. They noted that strong nominal wage growth even in the face of increases in the unemployment rate, high rates of long-term unemployment, and heavy reliance on fixed-term contracts and self-employment all point to the presence of significant rigidities in labor markets. Against this backdrop, Directors recommended measures to increase labor market flexibility, including changes in collective bargaining provisions to allow greater responsiveness to individual firm conditions, with a view to raising productivity, promoting wage moderation, and strengthening the economy's overall competitive position.

Directors welcomed the finding by the FSAP that Portugal's financial system is sound, well managed, competitive, and well supervised. They encouraged the authorities to implement the FSAP recommendations, and called on the authorities to continue to monitor risks closely. Continued vigilance will be important in a context of relatively high levels of household and corporate debt, concentration of bank lending to the real estate sector and to a limited number of large corporates, and exposure of banks' employee pension schemes to the stock market. While the financial system's profitability and solvency buffers appear to be capable of absorbing even severe disturbances to the macroeconomic environment, Directors cautioned that the system's capacity to respond to shocks should be reassessed periodically.

Directors looked forward to increases in Portugal's official development assistance toward the U.N. target level.

Public Information Notices (PINs) form part of the IMF's efforts to promote transparency of the IMF's views and analysis of economic developments and policies. With the consent of the country (or countries) concerned, PINs are issued after Executive Board discussions of Article IV consultations with member countries, of its surveillance of developments at the regional level, of post-program monitoring, and of ex post assessments of member countries with longer-term program engagements. PINs are also issued after Executive Board discussions of general policy matters, unless otherwise decided by the Executive Board in a particular case. 
Portugal: Selected Economic Indicators, 2002-07

\section{2} 2003 2004 $20051 /$ $20061 /$

Real economy (change in percent)

Real GDP

Domestic demand

$\mathrm{CPI}$ (year average, harmonized index)

Unemployment rate (in percent)

Gross national saving (percent of GDP)

Gross domestic investment (percent of GDP)

Public finance (percent of GDP)

General government balance

Primary balance

Public debt

Money and credit (end-period, percent change)

Total domestic credit

National contribution to euro area M3 2/

Interest rates (end-period)

Deposit rate, up to 2 years $3 /$

Ten-year government bond yield

Balance of payments (percent of GDP)

Trade balance

Current account (including capital transfers)

Net official reserves (in US\$ billions, end of period)

\section{Exchange rate}

Present rate (August, 2006)

Euro-area member

Nominal effective rate $(2000=100)$

Real effective rate $(2000=100)$

\section{Exchange rate regime}

$\begin{array}{rrrrrr}0.8 & -1.1 & 1.2 & 0.4 & 1.2 & 1.5 \\ 0.0 & -2.2 & 2.3 & 0.7 & 1.1 & 1.4 \\ 3.7 & 3.3 & 2.5 & 2.1 & 2.6 & 2.2 \\ 5.0 & 6.3 & 6.7 & 7.6 & 7.7 & 7.6 \\ 17.4 & 16.9 & 15.9 & 13.0 & 12.6 & 12.6 \\ 25.2 & 22.8 & 22.9 & 22.3 & 22.4 & 22.4\end{array}$

$\begin{array}{llllll}-4.2 & -5.3 & -5.3 & -6.0 & -4.6 & -3.7 \\ -1.3 & -2.5 & -2.7 & -3.3 & -1.7 & -0.8 \\ 55.5 & 57.0 & 58.6 & 64.0 & 67.6 & 68.7\end{array}$

$\begin{array}{rrrrrr}2.9 & 2.0 & 2.0 & 2.1 & \ldots & \ldots \\ -1.1 & 4.3 & 5.7 & 5.8 & \ldots & \ldots\end{array}$

$\begin{array}{llllll}2.9 & 2.0 & 2.0 & 2.1 & \ldots & \ldots \\ 4.5 & 4.4 & 3.6 & 3.5 & \ldots & \ldots\end{array}$

$\begin{array}{rrrrrr}-10.4 & -9.1 & -10.5 & -11.4 & -11.9 & -11.5 \\ -6.4 & -4.0 & -5.7 & -8.1 & -8.2 & -8.2 \\ 15.9 & 11.5 & 10.7 & 10.9 & \ldots & \ldots\end{array}$

Sources: Bank of Portugal; Ministry of Finance; and IMF staff estimates and projections.

$1 / 2005$ is estimate, and figures for 2006 and 2007 are projections.

2/ Excludes currency in circulation held by non-bank private sector.

$3 /$ Data refer to new deposits for 2002 and to the stock of of outstanding deposits thereafter. Before 2003 deposit rate with $91-$ 180 day maturity is reported. 